\title{
UN PERSONAJE ELUSIVO: LOS MONOS EN EL ESTILO CERÁMICO CASMA DE LA COSTA NORCENTRAL DE PERÚ (CA. 800-1350 DC)
}

\author{
AN ELUSIVE CHARACTER: MONKEYS IN THE CASMA CERAMIC STYLE FROM \\ THE NORTH-CENTRAL COAST OF PERU (AD CA. 800-1350)
}

\author{
Jorge Gamboa ${ }^{1}$
}

\begin{abstract}
La investigación arqueológica de las sociedades prehispánicas tardías de la costa norcentral de Perú, identificadas como Casma y extendidas entre los valles de Chao y Huarmey, revelan un notable desarrollo cultural y sociopolítico que, no obstante, contrasta con su escaso rol en el debate contemporáneo sobre los procesos culturales andinos. Esta contribución esta dirigida a analizar las representaciones cerámicas Casma del mono, un animal de las tierras bajas de Sudamérica ausente en estado silvestre en la costa norcentral peruana. Los primates fueron parte de la iconografía de las tradiciones Chimú y Lambayeque (900-1450 DC) de la costa norte. Sin embargo, el significado del mono en la ideología y la cultura visual Casma es menos comprendido. Esta investigación examina los conceptos de jerarquía y sumisión, así como los de otredad y celebración, reconocibles en las representaciones Casma de los primates. Los resultados pueden ser integrados a una perspectiva "norcentral" capaz de contribuir al debate de dos temas entrelazados: las relaciones entre las sociedades indígenas americanas y el mundo natural, y los sistemas de tráfico a larga distancia entre la Costa Pacífica y el bosque tropical sudamericano.
\end{abstract}

Palabras claves: América del Sur, Andes Centrales, costa norcentral de Perú, Casma, monos, cerámica.

Archaeological research on the late Prehispanic societies of the north-central coast of Peru (from the Chao Valley to the Huarmey Valley), now identified as Casma, reveals an outstanding cultural and political dynamism. Despite this, their role in the current debate on the Andean cultural processes is not very significant. This study focuses on the Casma vessels representing the monkey, an animal from the South American rainy lowlands not found in the north-central Peruvian coast. Primates were part of the iconography of Chimú and Lambayeque traditions (AD 900-1450), which developed to the north of the Casma area. However, the meaning of monkeys in the Casma ideology and visual culture is less known. This research examines the concepts of hierarchy and submission, in addition to otherness and celebration, recognizable in the Casma representations of primates. The results integrate a north-central coast perspective into the debate of two interlocked topics: the relationships between indigenous societies of America and the natural world, and the long-distance networks of traffic that articulated the Andean coast with the South American Neotropical forest.

Key words: South America, Central Andes, north-central coast of Peru, Casma, Neotropical monkeys, ceramics.

Los valles y desiertos de la costa norcentral de Perú, desde Chao hasta la actual frontera entre Ancash y Lima, albergaron entre ca. 800 y 1350 DC a las sociedades que ahora conocemos como "Casma". Los orígenes de esa vibrante, compleja y aún poco comprendida tradición cultural pueden ser encontrados en los siglos VIII a IX, en el periodo de interacción entre las sociedades de la costa y sierra centrales involucradas en la expansión Wari y las poblaciones Moche sureñas (Giersz 2016). El área descrita fue dominada de 1350 a 1450 DC por los Chimú, quienes construyeron el extenso centro administrativo de Manchán, siendo luego incorporada en el Chinchaysuyo, la región septentrional del Estado Inca (Mackey y Klymyshyn 1990). La organización sociopolítica Casma pudo alcanzar entre los siglos IX a XIV un rol vital en los sistemas de interacción regional que vinculaban tanto a la costa norte con la costa central como a esas tierras bajas occidentales con la sierra norcentral. Centros administrativos y ceremoniales costeños principales como Batán Grande, Túcume y Chan Chan -la capital Chimú- dependían de los caminos que recorrían el territorio Casma para alcanzar, al sur, las tierras Chancay e Ichma y el santuario de Pachacamac. Al este, las sociedades

\footnotetext{
${ }^{1}$ Escuela de Arqueología, Universidad Nacional Santiago Antúnez de Mayolo, Huaraz Ancash, Perú. jgamboavelasquez@yahoo.com
}

Recibido: marzo 2019. Aceptado: septiembre 2019.

http://dx.doi.org/10.4067/S0717-73562020005001002. Publicado en línea: 21-junio-2020. 
de las tierras altas de Ancash y del Alto Marañón pudieron interactuar con los Casma para acceder a los productos de la costa y el mar (Figura 1) ${ }^{1}$.

La existencia de cierto grado de unificación política a lo largo del área costera norcentral explicaría la dispersión de los rasgos culturales Casma (Vogel 2012, 2018; Wilson 1988:342). Un elemento a favor de esa propuesta es la recurrencia de formas cerámicas similares, con decoración moldeada, tricolor o incisa, empleadas en contextos de negociación política y religiosa a lo largo del territorio de Chao a Huarmey (Vogel 2011). Al mismo tiempo, la existencia de elementos locales compartidos, pero no idénticos sugiere que esas manifestaciones compartidas de producción de la materialidad Casma coexistían con expresiones de descentralización y complejidad organizativa que no corresponden exactamente a un modelo “imperial" (Vogel 2011:206; 2018:13). La tradición alfarera Casma encontraba una expresión distintiva en las vasijas "utilitarias" decoradas con incisiones, usadas tanto para preparar alimentos como en festividades y ceremonias funerarias (Bastiand 2006; Daggett 1983). Parte de esos contenedores servían para producir chicha de maíz, una bebida alcohólica asociada estrechamente a las prácticas de compromiso social y económico (Pozorski y Pozorski 2012; Vogel 2016:171-172).
El estudio de la iconografía de la tradición estilística Casma es un campo en definición y crecimiento. El sistema visual Casma incluía representaciones cerámicas de monos, un animal inexistente en estado silvestre en la costa norcentral peruana. Esas imágenes forman un corpus que, con la excepción del trabajo de Carrión Cachot (2005 [1955]), ha sido poco explorado. El artículo busca contribuir a definir el significado del mono entre las poblaciones prehispánicas tardías de la costa central. Para ello se examinan tanto el rol de los primates entre las sociedades indígenas andinas como las características icónicas del mono Casma, un motivo iconográfico convertido por la combinación de falta de estudios con su aparición recurrente en la producción alfarera regional en "oculto a simple vista". La principal fuente de datos usada es la información visual proporcionada por vasijas registradas en prospecciones y excavaciones arqueológicas, o carentes de procedencia y conservadas en museos. La articulación entre esas representaciones y las bases teóricas presentadas permitirá discutir la posición de los primates del Neotrópico en la ideología Casma de la costa norcentral, pero también nos llevará a revisar la posición del área en las rutas interregionales precoloniales. La investigación buscará finalmente aportar a una temática mayor: la comprensión de los
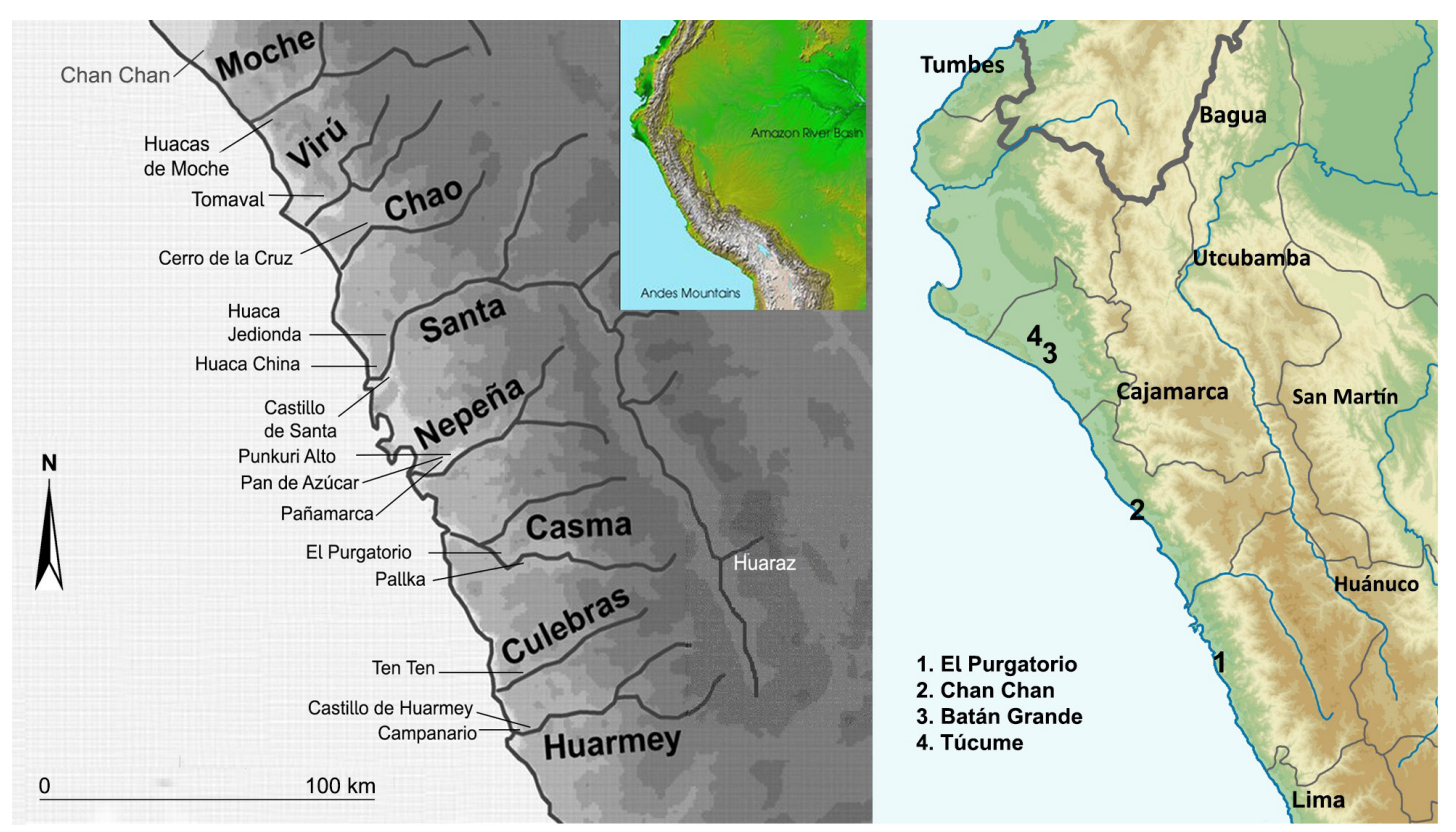

Figura 1. Costa norcentral de Perú y sitios representativos del área cultural Casma y regiones vecinas (elaboración Hoover Rojas). North-central coast of Peru and sites representative of the Casma cultural area and its neighboring regions (prepared by Hoover Rojas). 
vínculos entre las comunidades humanas y el mundo natural en la América precolombina (Alaica 2018; Chinchilla 2010; Götz y Emery 2013).

\section{Bases Teóricas}

Teoría. Las existencias del Homo sapiens y los primates no-humanos se encuentran profunda y complejamente entrelazadas. Este análisis tiene como punto de partida la aproximación etnológica multiespecies, definida por Kirksey y Helmreich (2010:545) como orientada a entender las relaciones humano-animales desde una perspectiva que reconoce a estos últimos como seres con agencia. Esta posición responde a un giro ontológico ideado para expandir el enfoque teórico de la antropología a un campo más amplio capaz de comprender las diversas, y cambiantes, formas de interacción entre las sociedades humanas y la naturaleza (Haraway 2008; Van Dooren et al. 2016). Van Dooren et al. (2016:16) propusieron que la antropología multiespecies debía ser considerada un ensayo de atención al otro animal. Esta manera de entender la realidad coloca a lo "humano" en un flujo continuo de capacidades y esfuerzos de múltiples fuerzas, humanas y no-humanas, y pone sobre el tapete las alteraciones antrópicas de los ecosistemas. Bajo esa visión renovada de la antropología -y de la propia arqueología- los primates son reconocidos como seres sociales y agentivos, en capacidad de formar parte (aunque forzadamente) de diversos contextos socioeconómicos.

Un punto de vista similar, e influyente en el anterior, fue explorado por Viveiros de Castro (1992, 1998) y Descola (2005), quienes identificaron en áreas como la Amazonia formas de entendimiento relacional -donde los seres son definidos a través de vínculos mutuos de origen, rol y jerarquía- en la construcción conceptual de humanos y animales. La mirada perspectivista de Viveiros de Castro, así como el análisis del animismo por Descola, atrajeron un nuevo interés académico y público en la observación de sistemas ideológicos que colocaban a los humanos en un medio dinámico de corporalidades, agencias y jerarquías entrelazadas con otros cuerpos animados. Para un contexto temporal y cultural diferente, Bouysse-Cassagne (2018) examinó las ontologías relacionales desarrolladas por algunas sociedades prehispánicas, específicamente de los Andes Meridionales, en torno a distintos animales silvestres constantemente buscados, deseados y "entendidos" por los primeros.

Las relaciones entre materialidades y ontologías en la costa septentrional de los Andes Centrales han sido recientemente tratadas por Swenson (2015) y Alaica (2018), ambas contribuciones enfocadas en el periodo Moche Tardío (ca. 600800 DC). Swenson (2015:677, 679, 707), en un estudio de espacios arquitectónicos y topológicos, empleó críticamente las nociones ontológicas arriba señaladas, indicando los riesgos de asumir una correlación directa entre diferencias y similitudes materiales y concepciones ontológicas (o filosóficas) opuestas o comparables. Por su parte, Alaica $(2018: 865,869)$ examinó el registro zooarqueológico e iconográfico Moche (100-800 DC) para aproximarse a la existencia de categorías, opuestas o no, de 'silvestre' y 'doméstico' en esa sociedad. Ese análisis le permitió sostener que la relación percibida entre ciertos personajes de alto estatus y animales fuertes y ágiles, era un medio empleado para expresar interioridades similares complementarias a corporalidades distintas (Alaica 2018: 869-870).

Zooarqueología. Uno de los registros zooarqueológicos más tempranos de la presencia del mono en los Andes Centrales corresponde al sitio Paloma (5800-2700 AC, Chilca) de la costa central, donde la tumba de un varón joven en Paloma presentó un fémur de mono araña Ateles sp. (Reitz 2003:78). Paloma era un asentamiento aldeano precerámico especializado en la explotación de los recursos marinos y que habría formado parte de una red de contactos con la Amazonia, situación que permitió el arribo de un mono araña, probablemente criado como mascota (Moseley 1992:104) o, al menos, de un elemento corporal de esa especie ${ }^{2}$. El Precerámico Tardío fue un primer momento de intensificación en los contactos de la costa central con la cuenca amazónica. Los centros ceremoniales de Caral y Aspero (3000-1800 $\mathrm{AC}$ ) en Supe, al sur de lo que milenios después sería el área Casma, han producido ornamentos y flautas en hueso con imágenes de animales identificados como monos (Shady y Leyva 2003:291).

La costa norte también ha producido evidencias tempranas de uso humano de los primates sudamericanos. La excavación del sitio ceremonial precerámico tardío (3000-1600 AC) de Ventarrón, en Lambayeque, condujo al registro de la osamenta de un machín Cebus albifrons enterrado durante un evento de renovación arquitectónica, un proceso que atestiguó la deposición de los restos corporales de varios animales silvestres (Alva 2013:141-142, 148, fig. 181). Las representaciones cerámicas de primates formaron parte siglos más tarde de los estilos Cupisnique (1500400 AC), Salinar (500 AC-100 DC) y Virú (100 AC-ca. 500 DC). El periodo Moche (ca. 300-800 DC) fue uno de abundancia en la producción de imágenes naturalistas o humanizadas de monos, algo que contrasta con el escaso número de datos zooarqueológicos sobre 
los primates en esa sociedad norcosteña. Los monos fueron representados por las poblaciones Lambayeque, Chimú, Inca y Colonial, apareciendo figurados en cerámica, objetos de metal, vasos kero, textiles y, a partir del siglo XVI, folios ilustrados.

El tráfico costeño prehispánico tardío de primates pudo extenderse al sur del territorio Casma. En Pachacamac, en el valle de Lurín, el cuerpo enfardelado de un mono machín Cebus albifrons fue reportado en un contexto dedicatorio Ichma (1000-1400 DC) (Eeckhout 2004:438, 441). En 1896, Max Uhle registró en el mismo centro religioso precolonial un textil con el diseño de un ave de carroña picoteando la cabeza de un animal identificado por Benson (1997:14, fig. 9) como un mono. La asociación de la costa central con los bosques tropicales también aparece mostrada en el estilo Chancay (1000-1532), en cántaros representando a un personaje humano con un mono y un loro en los hombros (Benson 1997:20). Los valles de la costa sur peruana, entre Pisco y Acarí, pudieron ser igualmente escenarios de la crianza en cautiverio de primates, un punto sobre el cual existen mayores evidencias iconográficas que contextuales (Knobloch 2005; Paul 1991:284).

Iconografía. El significado del mono en las sociedades prehispánicas de América ha sido objeto de análisis por autores como Baker (1992), Benson (1997:42, 60-66), Echevarría (2015) y Rice y South (2015). Esos estudios han remarcado en común la importancia de la apariencia antropomorfa del mono y el rol adquirido por ese animal en las narrativas de origen de la humanidad, un papel que le otorgaba un estatus elevado pero que, en paralelo, convertía a los primates en signos vivientes de escarnio y depravación. Otros aspectos pueden ser destacados. El mono era parte de los símbolos empleados en los ciclos calendáricos de Mesoamérica. En la ideología Moche, por otra parte, existía una relación estrecha entre los monos, el acceso a las hojas de coca procedentes de los valles cálidos, y la muerte (Benson 1997:64; Bourget 2006:40, 171).

La iconografía prehispánica del mono en la costa norcentral de Perú fue explorada por Rebeca Carrión Cachot (2005 [1955]), quien prestó atención a las figuras de primates presentes en los estilos cerámicos de la costa norcentral entonces conocidos como 'Huaylas-Yunga', 'Santa', 'Casma' o 'Pativilca'. Carrión Cachot (2005 [1955]:10, 133$134,146)$ reconoció en esas vasijas la aparición frecuente de personajes vinculados al maíz, la yuca y el ají; los monos formaban parte de ese repertorio, el que para la autora mostraba rasgos y significados comunes con los motivos asociados a las pacchas prehispánicas distribuidas desde Colombia hasta $\mathrm{Cusco}^{3}$. Para Carrión Cachot las pacchas -incluyendo aquellas con la representación de un mono- se hallaban constantemente vinculadas a la propiciación agrícola. El mono precolombino de la costa norcentral fue señalado por Carrión Cachot (2005 [1955]:75) como un "símbolo o figura emblemática relacionada con las lluvias", pero no llegó a convertirse en un tema específico de sus investigaciones. Los aspectos relacionales del mono Casma con los líquidos serán retomados en la parte final de este artículo ${ }^{4}$.

\section{La Tradición Cerámica Casma}

El área Casma comprendió la sección de la costa de los Andes Centrales atravesada por los ríos Chao, Santa, Lacramarca, Nepeña, Casma, Culebras y, al menos, Huarmey. Los sitios principales Casma estaban provistos de edificios públicos, ceremoniales y administrativos con patios y rampas, como los que aparecen en El Purgatorio, en el valle bajo de Casma, el asentamiento considerado por Vogel (2016) la capital regional de esa tradición. El paisaje rural alrededor de los centros primarios incluía numerosos sitios rurales, espacios sagrados, cementerios y lugares fortificados. En todos esos espacios se emplearon los tipos de cerámica identificados como Casma Tricolor, Casma Moldeado, Casma Inciso y Casma con Apliqué Serpentiforme (Daggett 1983; Proulx 1968; Vogel 2011:209-220). Las dos primeras modalidades caracterizaron la tradición alfarera de la costa norcentral desde el Horizonte Medio (800-1000 DC) hasta los inicios del periodo Intermedio Tardío (1000-1450 DC), de hecho, sus diseños pintados contienen con frecuencia motivos originados en la tradición estilística Wari. Las formas incisas y con elementos ornamentales aplicados pudieron surgir a fines del Horizonte Medio, continuando vigentes hasta la transición al periodo Colonial (Figura 2).

Los cántaros, vasos kero y botellas Casma con decoración tricolor y en relieve fueron elaborados con moldes y su cocción se realizaba en hornos abiertos o cerrados. Los motivos pintados y en relieve reproducidos en esos recipientes eran escénicos o geométricos. El grupo cerámico con decoración incisa incluía ollas y cántaros de cocción oxidante y mayor tamaño, volumen y peso, con una ornamentación exterior (a veces profusa) basada en el uso de punzones y sellos de caña o hueso (Bastiand 2006). Los diseños creados con esas herramientas podían ser combinados con bandas de color crema, figuras modeladas sencillas (Koschmieder 2012:figs. 11, 12) y bandas superpuestas figurando 


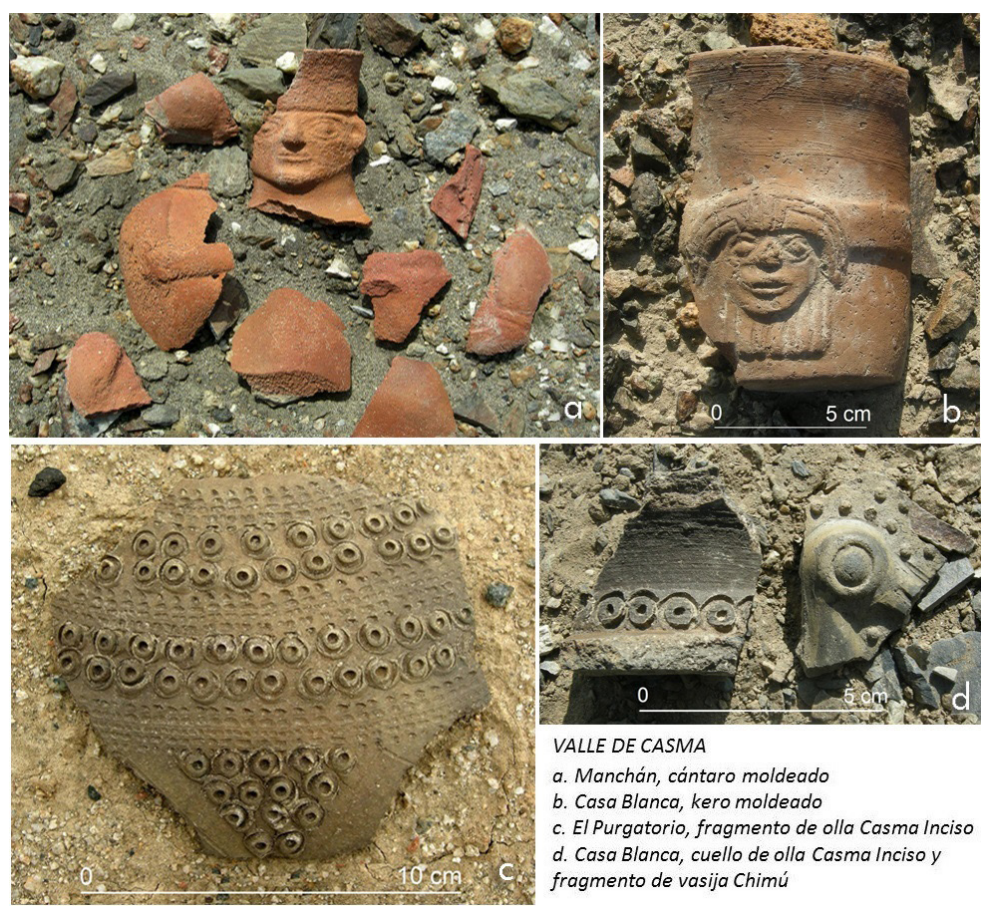

Figura 2. Cerámica de los tipos Casma Tricolor, Moldeado e Inciso de la costa de Ancash (foto J. Gamboa),

Casma Tri-color, Molded, and Incised ceramics from the Ancash coast (photograph by J. Gamboa).

serpientes y reptiles (Daggett 1983:212, 218-219). Las representaciones Casma del mono ocurren en todos los grupos descritos.

\section{La Iconografía Prehispánica Tardía del Mono en la Costa Norcentral}

\section{Cántaros con decoración tricolor}

Un primer conjunto de imágenes Casma del mono puede ser encontrado en cántaros con pintura tricolor. Un grupo de esas vasijas es conservado desde mediados del siglo XX en el Museo Regional de Ancash (MRA) en la ciudad de Huaraz. La mayoría de esas piezas (altura promedio de $22 \mathrm{~cm}$ ) presenta un rostro escultórico, humano o humanizado, en la base del cuello, una forma conocida en la arqueología peruana como "cara-gollete". El tratamiento escultórico en estas piezas se hallaba limitado a la parte alta del recipiente; de hecho, el cuerpo ovoide de los cántaros reemplazaba la corporalidad del personaje figurado en arcilla, que desaparece sin dejar mas huellas que, ocasionalmente, los brazos. Las cámaras mostraban imágenes pintadas antes de la quema.

El primer caso, con una peculiar base pedestal calada de color crema, presenta en el cuerpo el diseño pictórico de una cabeza animal en perfil de inspiración Wari. La cara-gollete correspondía a un personaje humano con pintura facial y orejeras. Los monos dispuestos junto al cuello fueron elaborados mediante modelado y moldeado. Esta última técnica fue reservada para las cabezas, redondeadas y con orejas prominentes, como las de un machín Cebus albifrons (Figura 3a-b). Las bocas fueron creadas mediante una incisión. Los cuerpos de cada animal fueron pintados de negro, pero se empleó pintura crema alrededor de los ojos; la postura corporal adoptada era similar: sentados y con una larga cola haciendo una curva sobre la pared de la vasija. Las extremidades superiores estaban originalmente levantadas y al menos uno de los brazos tocaba la oreja del individuo humano, pero, en lugar de observar la figura, ambos primates dirigían su mirada al frente del cántaro.

La segunda vasija presenta en el cuerpo bandas diagonales pintadas y dos figuras escultóricas de monos (Figura 4). La cabeza moldeada del primate que ha llegado completo hasta nuestros días es marcadamente naturalista, mostrando una frente triangular prominente y grandes orejas. Bajo la cabeza, ambos cuerpos animales habrían sido modelados y carecen de pintura. A diferencia del caso anterior, estos primates adoptaban una posición cuadrúpeda. En ninguno de ellos se empleó pintura para remarcar el rostro o los ojos. La imagen completa 


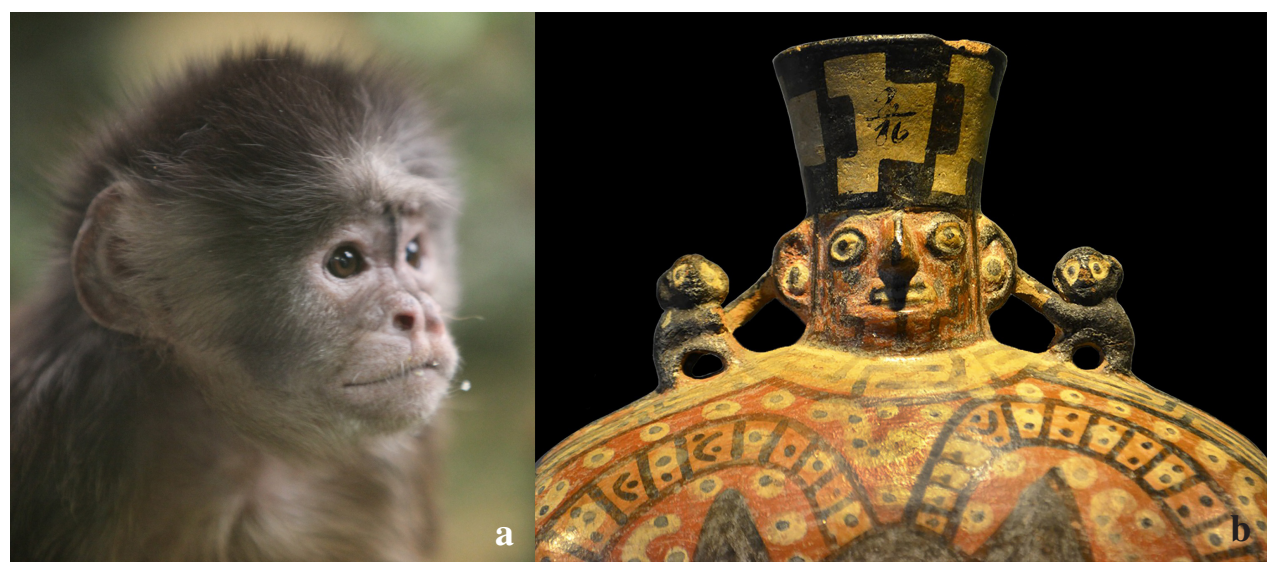

Figura 3. (a) Cebus albifrons, foto por Rama, Wikimedia Commons, Cc-by-sa-2.0-fr. (b) Vasija con decoración tricolor en Museo Regional de Ancash, Ministerio de Cultura del Perú, Huaraz (foto J. Gamboa 2014).

(a) Cebus albifrons, photograph by Rama, Wikimedia Commons, Cc-by-sa-2.0-fr. (b) Vessel with tri-color decoration at the Regional Museum of Ancash, Peru's Ministry of Culture, Huaraz (photograph by J. Gamboa 2014).

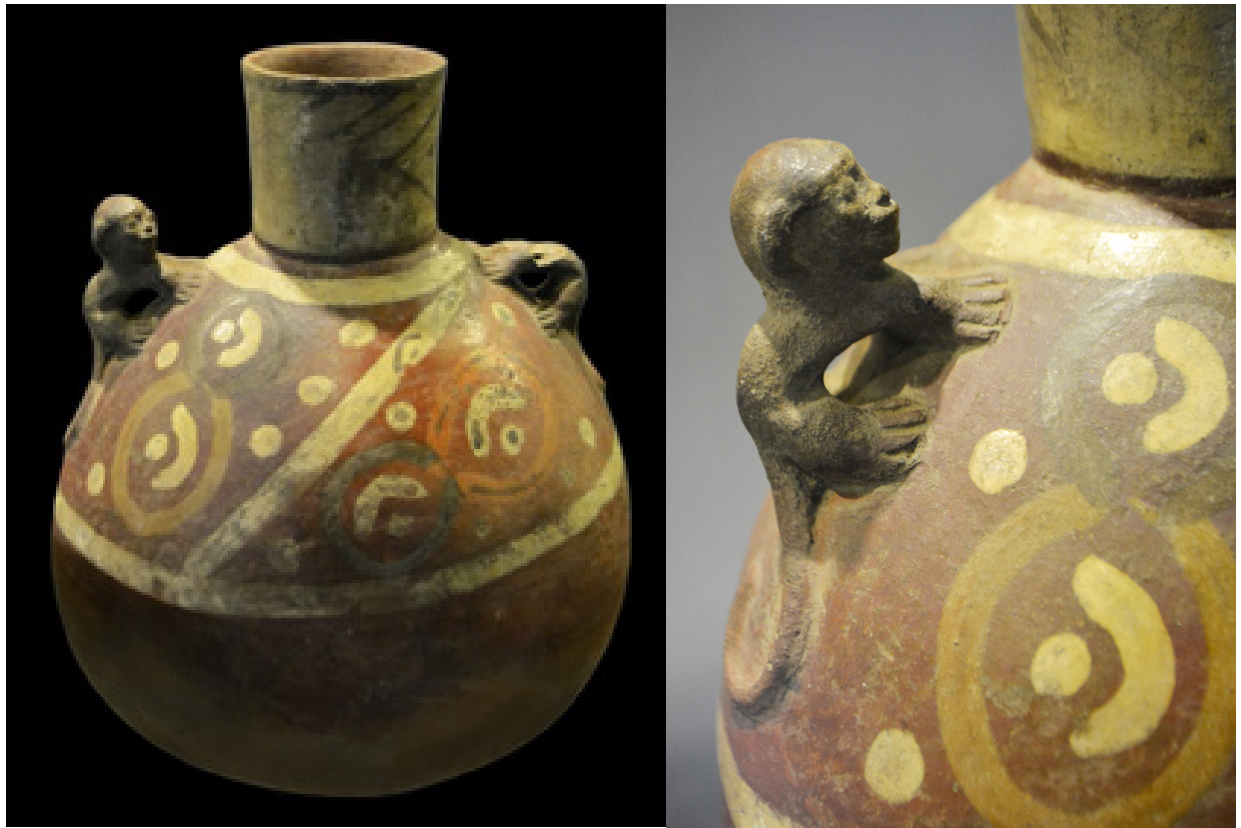

Figura 4. Vasija con decoración tricolor en Museo Regional de Ancash, Ministerio de Cultura del Perú, Huaraz (foto J. Gamboa 2014). Vessel with tri-color decoration at the Regional Museum of Ancash, Peru's Ministry of Culture, Huaraz (photograph by J. Gamboa 2014).

puede ser identificada como correspondiente a un Cebus albifrons, presente en Tumbes, la costa de Ecuador y la cuenca del Amazonas, o un Sapajus sp., un primo del anterior que habita la mayor parte del bosque tropical amazónico.

Otro cántaro presenta el rostro escultórico de un personaje antropomorfo con colmillos y "orejas" zoomorfas. La parte media del gollete tenía una banda de relieves geométricos a la manera de un tocado. El cuerpo de la vasija fue decorado con el perfil de una cabeza zoomorfa con apéndices (Figura 5). Como ya resulta usual, un par de pequeños monos fue añadido a los lados del cuello. Uno de ellos se fragmentó en algún momento de la historia de vida del recipiente. El primate del lado derecho del cántaro fue modelado y careció de pulido y pintura. Su cabeza, dispuesta hacia el frente de la vasija, tenía rasgos simplificados, con esferas aplicadas en nariz 


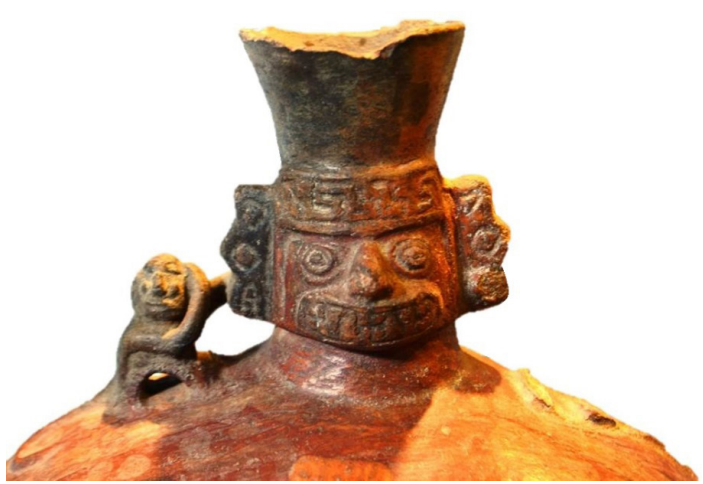

Figura 5. Vasija con decoración tricolor en Museo Regional de Ancash, Ministerio de Cultura del Perú, Huaraz (foto J. Gamboa 2017).

Vessel with tri-color decoration at the Regional Museum of Ancash, Peru's Ministry of Culture, Huaraz (photograph by J. Gamboa 2017).

y ojos y boca creada expeditivamente mediante una incisión. El brazo izquierdo del mono se extendía hasta tocar la oreja del ser sobrenatural; el brazo derecho, por el contrario, tocaba el lado izquierdo de la cabeza del propio animal.

Un cántaro de cuerpo compuesto y caragollete humana incluye un ejemplo adicional de representación del mono (Figura 6). El frente y los lados de la vasija fueron pintados con motivos en $\mathrm{S}$ y símbolos escalonados; la parte superior del

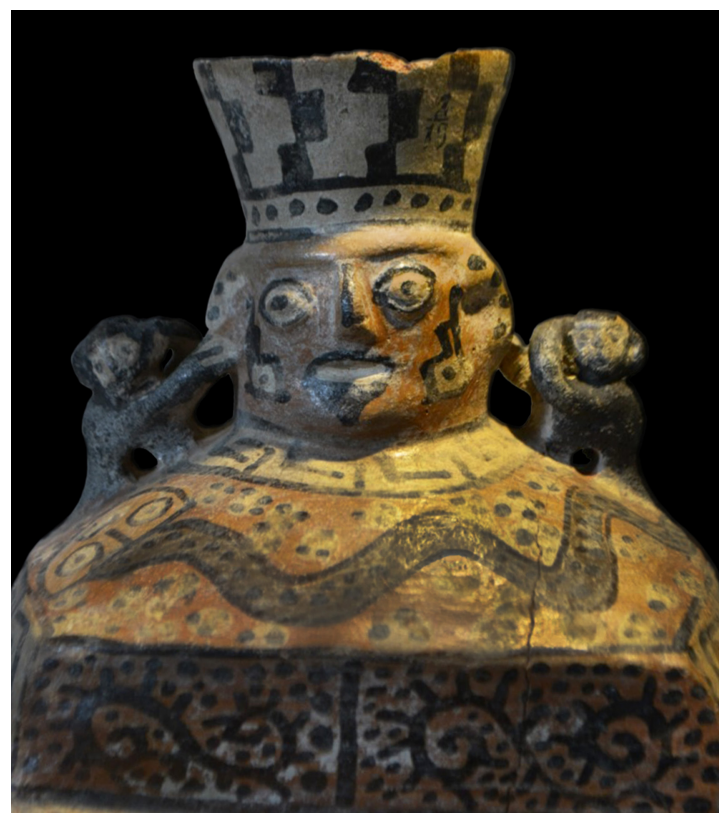

Figura 6. Vasija con decoración tricolor en Museo Regional de Ancash, Ministerio de Cultura del Perú, Huaraz (foto J. Gamboa 2017).

Vessel with tri-color decoration at the Regional Museum of Ancash, Peru's Ministry of Culture, Huaraz (photograph by J. Gamboa 2017). cuerpo fue reservada para diseñar dos serpientes, ondulantes y con cabeza semicircular. Sobre las serpientes se levantaba el cuello del vaso y su rostro escultórico con pintura facial, orejeras y tocado de diseños geométricos. Flanqueando a ese personaje se encontraban dos monos sentados, con cuerpo de color negro y rostros crema. En cada primate un brazo se levantaba para tocar una de las orejas humanas; la otra extremidad se posaba sobre el lado correspondiente de la cabeza animal. Rompiendo la simetría en espejo de otros ejemplos, los brazos extendidos hacia el personaje central eran los mismos. La extremidad erguida del mono en el lado izquierdo de la cara-gollete era la derecha; si bien tomaba una posición opuesta, el segundo primate levantaba el mismo brazo. La boca, frente y orejas de estas imágenes sugieren nuevamente la identidad de un mono machín. Un detalle no visto en otras piezas debe ser destacado: el lado posterior de la cabeza de cada monito tenía un segundo rostro.

El quinto cántaro del MRA representa a un músico humano con cara pintada de rojo y orejeras. Los brazos añadidos al recipiente sostenían una quena. El frente del cuerpo fue pintado con la imagen de un ser zoomórfico con cuerpo en forma de voluta con escalones (Figura 7). Junto a la cabeza humana aparecían dos monos dispuestos en un patrón simétrico. Las cabezas de los primates,

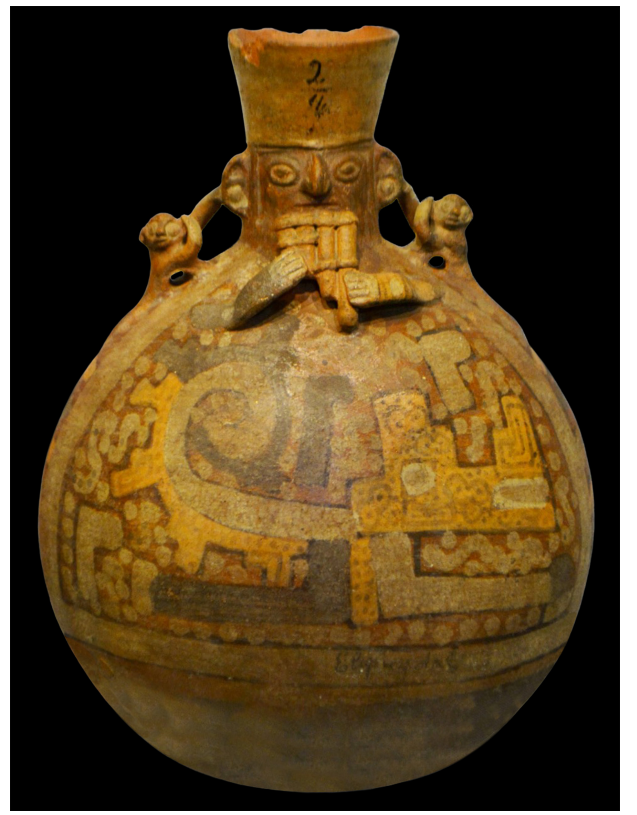

Figura 7. Vasija con decoración tricolor en Museo Regional de Ancash, Ministerio de Cultura del Perú, Huaraz (foto J. Gamboa 2017).

Vessel with tri-color decoration at the Regional Museum of Ancash, Peru's Ministry of Culture, Huaraz (photograph by J. Gamboa 2017). 

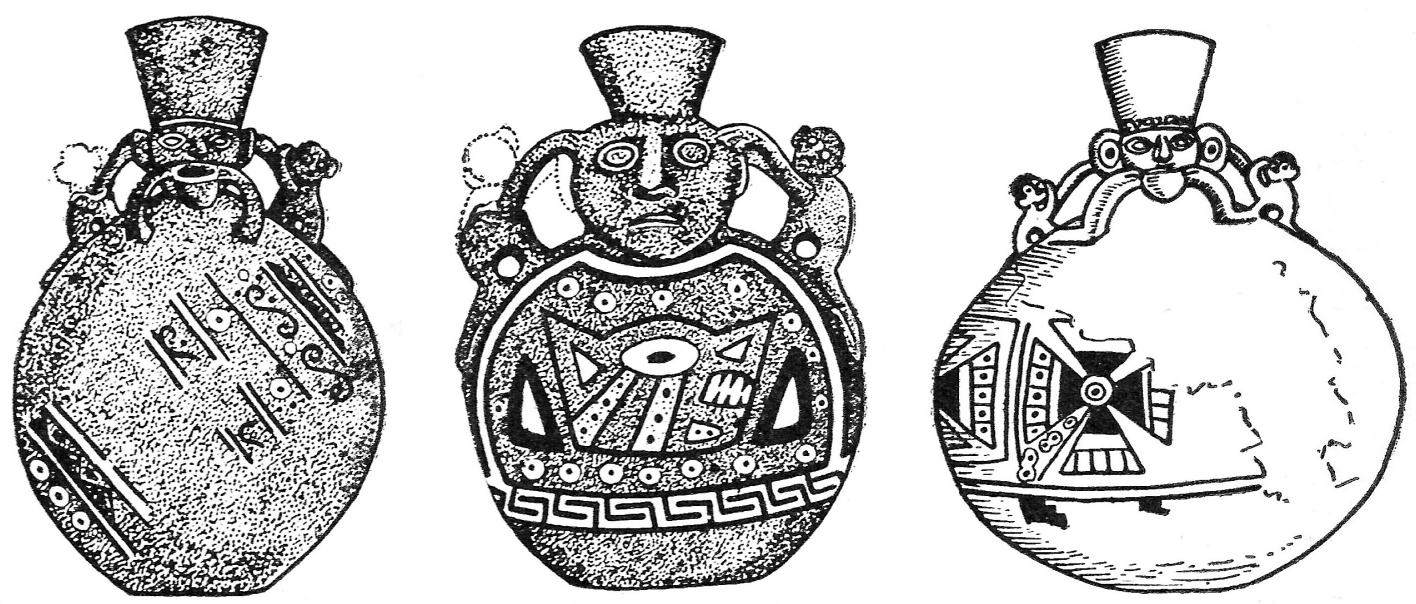

Figura 8. Cántaros del Valle de Casma con figuras de mono (Tello 1956:fig.150).

Casma Valley's vessels with monkey figures (Tello 1956:fig 150).

de ojos circulares y boca incisa, miraban al frente de la vasija, siguiendo la posición del personaje central. El brazo izquierdo del mono a la derecha de la cara-gollete se extendía hasta la cabeza humana; la extremidad superior derecha del animal tocaba, en cambio, su propia oreja izquierda. El orden de los brazos levantados se invertía en el mono a la izquierda del músico.

El libro póstumo de Julio C. Tello (1956:fig. 150d-f) sobre la arqueología prehispánica del Valle de Casma incluyó el dibujo de tres cántaros tricolor con figuras escultóricas de monos (Figura 8). Pertenecientes a una colección local documentada en 1937, esas vasijas fueron identificadas por Tello como parte del "estilo Santa o Huaylas Yunga". Cada una de estas piezas mostraba un rostro humano central y pares de monos escultóricos. Dos vasijas mostraban al personaje antropomorfo bebiendo de un vaso. Bandas oblicuas con signos en $\mathrm{S}$, la cabeza zoomorfa de perfil y símbolos en $\mathrm{X}$ fueron pintados en los cuerpos. Los símbolos geométricos Casma no deben ser considerados una simple marginalia; por el contrario, es del todo posible que contaran con significado propio. Un fragmento de cántaro con la representación del personaje realizando el acto de libación es actualmente conservado en el Museo Max Uhle de Cerro Sechín (Figura 9); a diferencia de los bebedores ilustrados en la obra de Tello, la banda-tocado tenía relieves en forma de cruz.

El sector central de El Purgatorio produjo en años más recientes un fragmento de asa con la cabeza escultórica de un mono con rostro naturalista (Vogel 2011:216, Tabla 3, fig. 30). Esa pieza fue registrada en el Sector A del sitio -un espacio con arquitectura

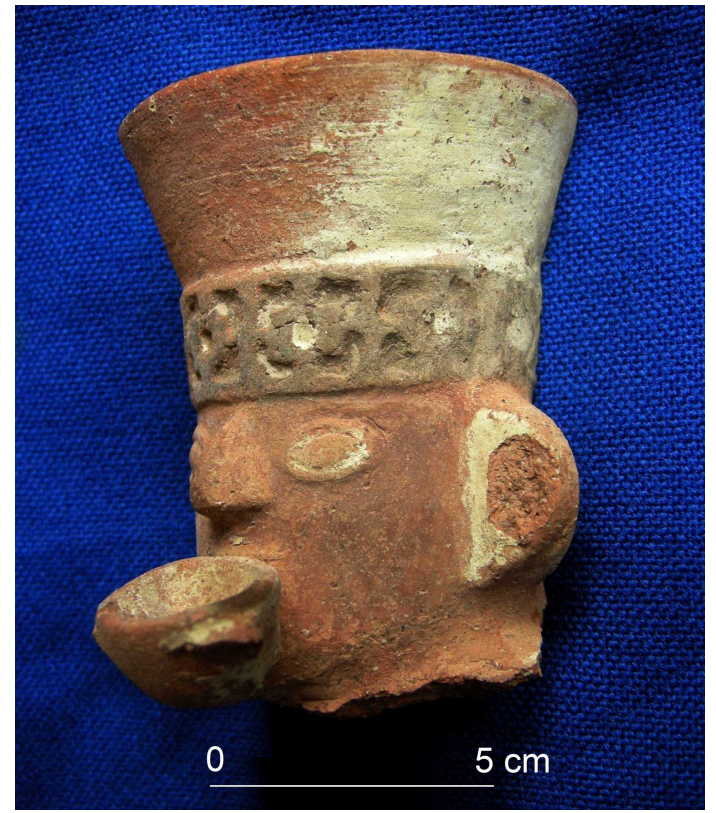

Figura 9. Cuello de cántaro tricolor con representación de personaje bebiendo, Museo de Cerro Sechín (foto J. Gamboa 2013).

Neck a vessel with tri-color decoration belonging to the local Capellania's local collection, Nepeña (photograph by J. Gamboa 2017).

monumental-, en un nivel excavado datado en cal. 1280-1391 DC AA82287 (carbón). Vogel, en base a la presencia de elementos cerámicos adicionales, consideró que la pieza podía corresponder al estilo Chimú; su semejanza a algunos de los materiales descritos sugiere sin embargo que se trataría de otra representación Casma de un primate. $\mathrm{La}$ cabeza zoomorfa de esa representación fue, con toda probabilidad, elaborada con molde. El uso de 
la técnica del moldeado por los alfareros Casma ha sido observado en sitios como El Purgatorio y Cerro la Cruz (Vogel 2011:212) ${ }^{5}$. Un antecedente de esa práctica se encuentra en el asentamiento Moche de San José, en Lacramarca al sur del valle de Santa, donde se documentó un molde usado para producir pequeñas aplicaciones cerámicas en forma de mono sentado (Chapdelaine et al. 2009:56).

El estilo cerámico Black-white-red del Valle de Nepeña fue identificado por Proulx (1968) y Daggett (1983) como coexistente con las formas incisas y con aplicaciones lineales. Un par de vasijas con pintura tricolor conservadas en el centro poblado rural de Capellanía, cercano al sitio Moche de Pañamarca, permite examinar la representación del mono en uno de los sectores de ocupación prehispánica más importante del área (Trever et al. 2017) ${ }^{6}$. Con decoración pictórica en la parte alta del cuerpo y el cuello, el primero de esos cántaros muestra la figura escultórica de un mono sentado sobre uno de los hombros de la vasija (Figura 10). Este primate fue mostrado con el torso erguido y brazos levantados para coger los lados del gollete. El lado opuesto de la vasija fue ocupado por un asa perforada. La segunda pieza de Capellanía también presentó una única figura escultórica de mono. El cuerpo del animal se encuentra quebrado, restando solo

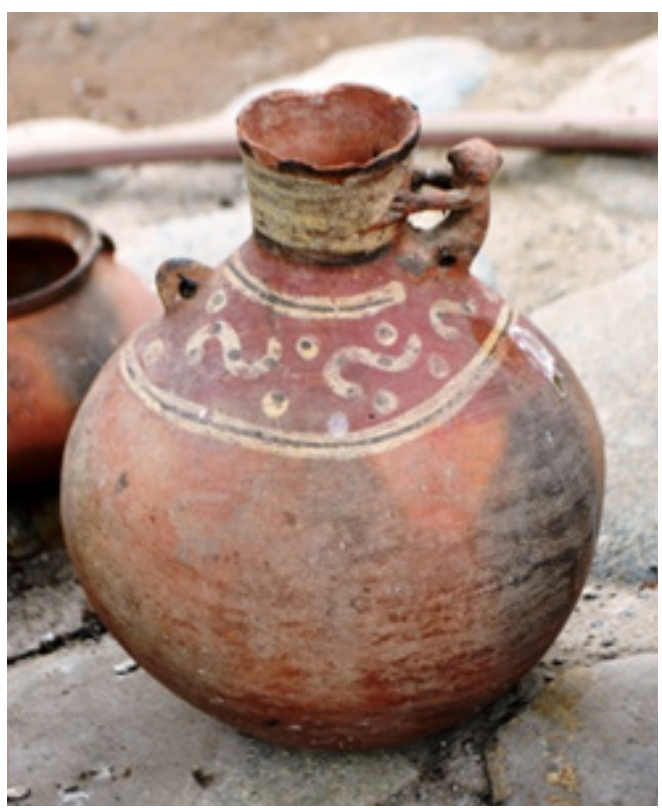

Figura 10. Vasija con decoración tricolor en colección local de Capellanía, Nepeña.

Vessel with tri-color decoration belonging to the local Capellania's local collection, Nepeña (photograph by J. Gamboa 2017). los pies y la cola curvada. No obstante, es posible observar un ordenamiento visual que colocaba al mono en el centro de una composición formada por dos símbolos escalonados que, rodeando la parte inferior del cuerpo del primate, ocupaban un espacio rectangular demarcado por bandas crema. El lado opuesto del recipiente conservaba la figura pintada de una serpiente bicéfala.

El conjunto iconográfico del mono Casma en Nepeña puede ser ampliado gracias a una investigación anterior. Donald Proulx (1968) no solo condujo la primera prospección intensiva del valle; su estudio de los patrones de asentamiento locales permitió registrar el notable crecimiento demográfico de la cuenca durante el Horizonte Medio y el periodo Intermedio Tardío. Las representaciones cerámicas de animales presentes en los sitios con alfarería tricolor de ese tiempo incluían imágenes de monos, sapos y aves, pero también de felinos y cánidos (Proulx 1968:41-42, 43). Proulx (1968:lám. 16b, d) publicó dos cántaros pintados completos con figuras escultóricas de monos en la base del gollete.

\section{Vasijas con decoración incisa}

La cerámica Casma no siempre muestra fronteras claras entre las categorías cerámicas "domesticas" y "ceremoniales". La excavación por Lorenzo Samaniego $(1974,1982)$ de los niveles Casma de Cerro Sechín, en el valle de Casma, condujo al registro de tumbas y espacios residenciales con evidencias adicionales de la figura del mono, esta vez en cántaros elaborados manualmente. Con dimensiones superiores a las vasijas pintadas, esas piezas tenían paredes gruesas, superficies alisadas e índices más altos de volumen y peso. En cada caso, una pareja de monos ocupaba la posición vista en las piezas antes examinadas. Sin embargo, los cántaros de Cerro Sechín no presentaban cuellos escultóricos; sus vertederas fueron ornamentadas únicamente con círculos impresos, nódulos y líneas crema (Figura 11 a-c). El cuerpo de los monos estaba superpuesto a las asas funcionales de las vasijas, con cada una de esas agarraderas habiendo sido recubierta con tiras de arcilla aplicadas para dar forma a la cola, extremidades y cabeza del animal; los ojos fueron asimismo diseñados mediante círculos incisos con punto central. Un ejemplar adicional de ese tipo de asa zoomorfa de Cerro Sechín fue publicado por Bastiand (2006:117).

Quienes crearon esas efigies pusieron cuidado en trasladar a la arcilla la corporalidad idealizada del mono graficada en las vasijas previamente descritas. 


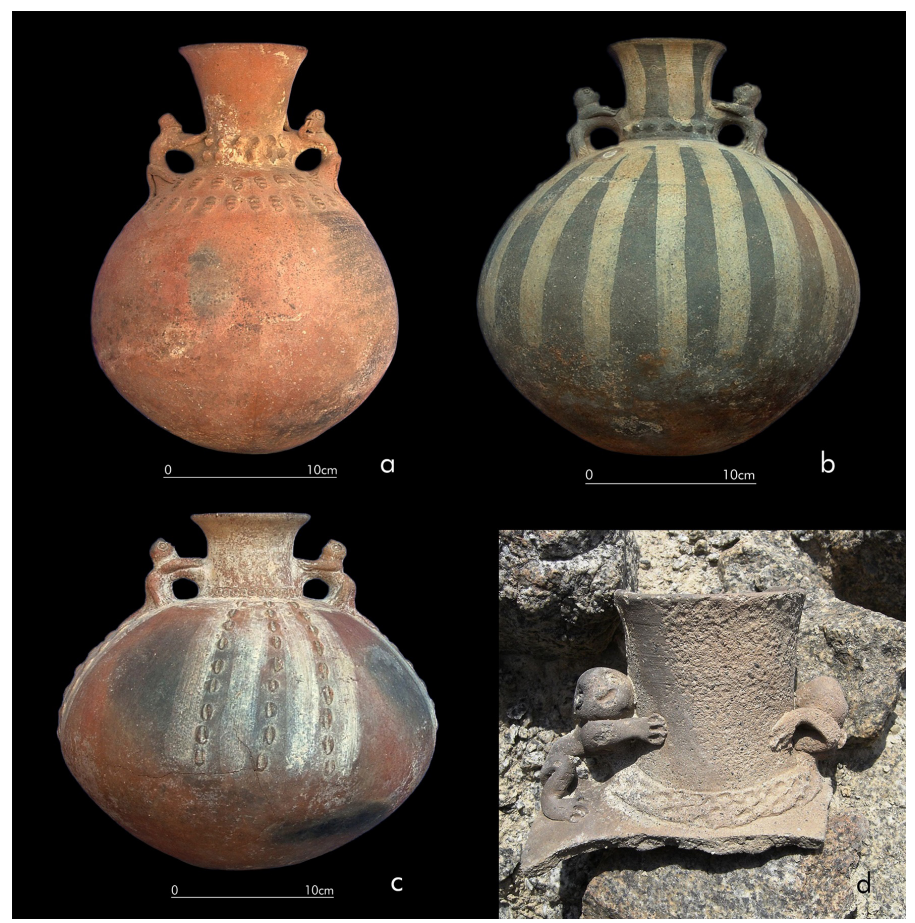

Figura 11. Cántaros Casma Inciso con monos (a-c) Museo Regional Max Uhle de Cerro Sechín, Casma (foto J. Gamboa 2013). (d) Caylán (foto J. Gamboa 2007).

Monkey-incised Casma vessels (a-c) Max Uhle Regional Museum of Cerro Sechín, Casma (photograph by J. Gamboa 2013). (d) Caylan (photograph by J. Gamboa 2007).

En uno de los cántaros (con huellas de hollín) de Cerro Sechín los monos fueron mostrados sentados, con cola extendida y cabeza ladeada, tocándose el rostro con la mano izquierda y con el brazo derecho tentando el gollete. Un segundo recipiente, con bandas de pintura crema en el cuello y el cuerpo, poseía un par de monos con cabeza y brazos orientados hacia el gollete. El cuello de un último cántaro fue cubierto con engobe blanco, que también sirvió para pintar sobre la cámara bandas anchas intercaladas con nódulos aplicados; la unión del gollete con el cuerpo fue remarcada con una hilera de círculos estampados. En este cántaro, los monos dirigían su mirada al borde del cuello, extendiendo sus manos hasta esa sección de la pieza.

\section{Cronologías y Estilos Locales}

La falta de contexto en varias de las representaciones cerámicas de primates antes presentadas amerita examinar la información existente sobre las ocupaciones prehispánicas tardías del área entre Chao y Huarmey. Empecemos por esa última cuenca ${ }^{7}$.

Huarmey. Hacia 800 DC, el sitio Castillo de Huarmey -uno de los primeros asentamientos de los Andes en emplear quipus- fue el centro político y ceremonial Wari más importante de la costa norcentral. Las vasijas de pasta gris allí registradas muestran rasgos afines a los estilos Casma Moldeado y, para un grupo de piezas con relieves del "animal lunar", Moche (Giersz 2016:fig. 26). La cámara funeraria de un varón adulto acompañado por una mujer tejedora presentó dos orejeras de madera con figuras de monos (Giersz 2016:251, fig. 25), un elemento sobre el que volveremos luego. Acorde con el probable carácter multiétnico del asentamiento, los textiles empleados localmente combinaban técnicas y diseños Wari, Moche y de la costa sur (Prümers 2000). Entre 1000 y 1400 DC, Campanario reemplazó a Castillo de Huarmey como el sitio primario del valle. Este nuevo asentamiento fue ocupado por poblaciones que empleaban tipos cerámicos incisos y moldeados; la cerámica tricolor era en cambio escasa (Zavaleta y Sánchez 2013:133, 148, 156). No sorprendentemente, algunos materiales de Campanario muestran similitudes con tradiciones alfareras contemporáneas de Pativilca a Chancay al sur (Kroeber 1925:240-253), zonas que también contaban con imágenes cerámicas de monos (Morgan 1996:382, 385, lám. 56).

Culebras. Los periodos Molino (700-850 DC) y Santa Rosa (850-1000 DC) fueron considerados por Giersz y Prządka (2009:10) representativos del tiempo 
aquí examinado, el mismo que, para esos autores, fue de ausencia de unidad política entre Culebras y otros valles. El repertorio iconográfico Casma Impreso con Molde local de ambos periodos presentaba motivos geométricos, así como escenas de personajes con cetros o bajo un arco bicéfalo, parejas radiantes y felinos enfrentados o sobre una luna creciente. El periodo Ten Ten (1000-1450 DC) vio el aumento de la complejidad socioeconómica del valle de Culebras (Prządka 2012:351). Las formas cerámicas Ten Ten más abundantes corresponden al estilo Casma Inciso -presente de acuerdo a Giersz y Prządka (2009:12) de Virú al valle de Fortaleza- e incluyen representaciones modeladas de monos, serpientes y aves. El periodo Chacuas Jirca (1450-1532 DC) atestiguó la continuidad de la producción de cerámica incisa dentro del área (Giersz y Prządka 2009:13).

Casma. Las vasijas de El Purgatorio permiten examinar la variabilidad de formas y técnicas decorativas de la cerámica del Horizonte Medio e inicios del periodo Intermedio Tardío en el valle bajo de Casma (Vogel 2011:figs. 6, 12,14). La producción alfarera de ese asentamiento incluía piezas de uso cotidiano y recipientes moldeados con imágenes pintadas o en relieve de felinos, seres sobrenaturales y personajes antropomorfos. Mostrando la amplitud de las fuentes culturales Casma, algunas vasijas presentaban figuras de felinos de perfil con una banda horizontal en la frente, un motivo más frecuente en el estilo Recuay de la sierra ancashina (Vogel 2011:fig. 14; también Tello 1956:fig. 143d). Aunque carecen de figuras de mono, dos cántaros del Cementerio 1 de El Purgatorio muestran afinidad a las piezas tricolor antes discutidas (Vogel 2011:figs. 19 y 20).

Santa. Las fases Tanguche Temprano (650-900 DC), Tanguche Tardío (900-1150 DC) y Tambo Real (1150-1450 DC) fueron los periodos prehispánicos de mayor densidad poblacional del valle bajo de Santa (Wilson 1988:224-294). Una tumba Tanguche Temprano de Huaca China (Chapdelaine et al. 2004:60-65, fig. 3) permite aproximarnos a la complejidad social detrás de las vasijas tricolor y moldeadas. El entierro perteneció a un hombre de 3035 años, robusto y con la dieta de los agricultores de su tiempo. Las ofrendas a su alrededor pertenecían a un conjunto asociado estilísticamente tanto a la tradición Casma como a la producción alfarera del valle de Moche (Castillo 2018:fig. 19; Donnan y Mackey 1978:214-289). Un cántaro tricolor presentaba la figura de una serpiente bicéfala rodeada por signos escalonados y cabezas "Wari" de perfil; el mismo contexto conservaba cuencos trípode, platos, una olla moldeada y un huso de madera. La tumba careció de piezas Casma Inciso, reportadas en otras partes del asentamiento. La excavación de un área residencial y de producción cerámica en el sitio Castillo de Santa fechada entre 900-1150 DC complementa la información de Huaca China. Los datos de ambos asentamientos condujeron a Bélisle (2008:26, fig. 6) a proponer que la Fase Tanguche Temprano sería más tardía de lo pensado, datando entre 800 y 1100 DC.

Chao y Virú. Representando un sector de confluencia de tradiciones estilísticas, los valles de Chao y Virú son un espacio crucial para el periodo en estudio. Cerro La Cruz, en Chao, fue un sitio fortificado Casma ocupado entre 890-1290 DC por poblaciones que empleaban vasijas con motivos incisos, moldeados y pintados (Vogel 2012, 2018:11). El abandono del asentamiento estuvo asociado a eventos de quema violenta o ritual durante el inicio de la presencia Chimú en el área. Los grupos de la Fase Tomaval del Valle de Virú contaban con vasos moldeados y tricolor, pero solo ocasionalmente usaban piezas Casma Inciso (Collier 1955:109, 120, 135, 160, fig. 60c; Strong y Evans 1952:205); por su parte, el tipo cerámico San Nicolas Molded de Virú mostraba relieves geométricos y círculos impresos (Collier 1955:fig. 57).

\section{La Construcción Ontológica del Mono Casma}

\section{Animales en la iconografía de la costa norcentral}

El mundo iconográfico Casma fue uno multiespecies. En El Purgatorio, además de las imágenes zoomorfas antes descritas, aparecen apliqués cerámicos de un reptil, posiblemente el "cañán" costeño Dicrodon guttulatum. En Caylán, al norte de Pañamarca, se encuentran asas de cántaro en forma de mono comparables a las reportadas en Cerro Sechín (Figura 11d). El pez ribereño "life" Tricoanycterus sp. puede ser identificado en la cerámica moldeada de Huaca China (Chapdelaine et al. 2004:66). Las sociedades Casma criaron camélidos, perros y cuyes (Cavia porcellus); sin embargo, la fauna doméstica y los cérvidos no fueron motivos predilectos de los ceramistas, quienes concentraron su atención e imaginación en la corporalidad de animales cazadores y silvestres (Bastiand 2006:112). El mono -omnívoro y no necesariamente agresivo- es una excepción a esa regla.

Con cuerpo moteado o llano, los felinos constituían una categoría importante de la iconografía cerámica Casma. Pumas, jaguares o gatos monteses (Leopardus jacobita) fueron mostrados en posición rampante, sosteniendo un cetro o porra, o con lenguas transformadas en serpientes (Tello 1956:310, fig. 143 a-c). Como en otras tradiciones icónicas andinas, los monos y los felinos tienden a confundirse en la cultura visual Casma. En algunos casos, pequeños animales 
con apariencia indistinta de primate o felino fueron representados junto a un ser humano flanqueado por "jaguares" (Tello 1956:fig. 146), un tipo de composición popular durante el Horizonte Medio e inicios del periodo Intermedio Tardío en la costa norte y norcentral y las tierras altas de Ancash (Figura 12a).

Las aves de la iconografía Casma eran marinas o cazadoras; esas especies parecen incluir pelícanos, piqueros Sula sp., cormoranes (Vogel 2011:figs. 18, 31 , halcones y cernícalos. Los rasgos de las aves de presa fueron prestados a un grupo de seres con elementos ornitomorfos diseñados a partir de modelos tanto Wari y de los Andes altiplánicos (García et al. 2018:551; Tello 1956:fig. 150i; Vogel 2011:figs. 25, 26) como de la tradición Moche (Figura 12b) ${ }^{8}$. Los personajes zoomorfos descritos se hallaban ordenados en jerarquías relacionales que colocaban a los animales cazadores en posiciones de mayor prestigio al tiempo que disponían sobre ellos a entidades híbridas -serpientes bicéfalas y felinos alados- o antropomorfas. El mono aparecía subordinado a ambas categorías de grupos de seres no-humanos de la iconografía costeña norcentral.

\section{La corporalidad del primate y los cántaros Casma}

Representado en parejas o solo, el mono Casma contaba con precedentes iconográficos regionales en los estilos Moche IV y Mochica Tardío (c.600800 DC). En Moro, Jequetepeque, los monos aparecían en el asa de las botellas Moche con escenas de entierro, navegación y combate (Donnan y McClelland 1999:139-183; McClelland et al. 2007); al igual que en las vasijas Casma, los monos Mochica

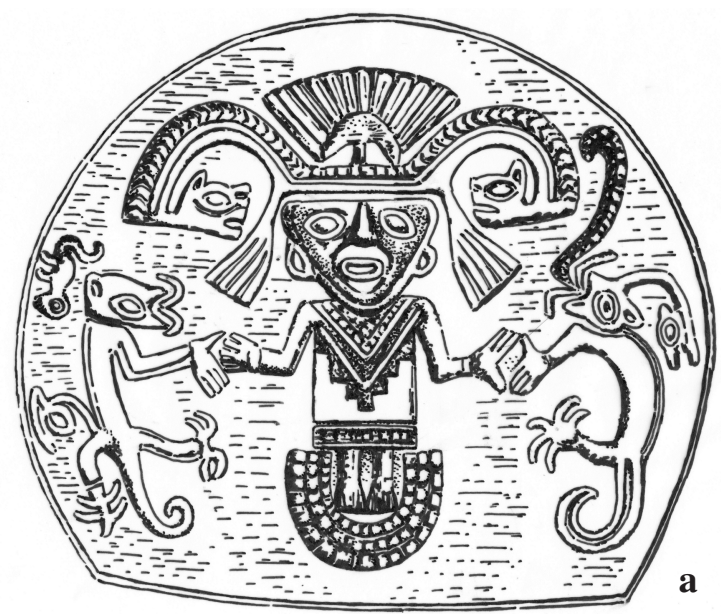

Tardío del estilo de Moro (600-850 DC) podían mostrar cabezas ladeadas. El mono cautivo, provisto de una correa alrededor de la cintura, fue un motivo apreciado por los Moche y, luego, por los Chimú. Sin embargo, en la iconografía Casma los monos carecían del cordel atado a sus cuerpos, siendo presentados en aparente libertad, sin superponer sus rasgos faciales a aquellos de los seres humanos y sin tomar la indumentaria de estos últimos. La carencia de transfiguración de lo primate a lo humano, así como la idealización de su capacidad de movimiento, tienden a definir el carácter ontológico del mono Casma; esos atributos también emergen como distintos a los reproducidos en las imágenes Moche y Chimú.

La especie Cebus albifrons habría sido la preferida para ser representadas por los ceramistas Casma, quienes usaron pintura crema para resaltar sus rostros de color claro. No obstante, sería prematuro descartar que otras especies de primates fueran objeto de similar atención en la costa norcentral. Benson (1997:65) consideró que los Saimiri sciureus, más pequeños que los machines y otra alternativa para algunas de las imágenes cerámicas Casma arriba discutidas, fueron conocidos por los Moche. De comprobarse la crianza en cautiverio de primates en sitios residenciales y ceremoniales Casma, deberá evaluarse aspectos como la abundancia relativa de esos individuos, sus modificaciones en tamaño, morfología y conducta por efecto de la alimentación y actividades impuestas por (o aprendidas de) el ser humano, o la incidencia de enfermedades y patologías afectando su salud y reproducción.

La reiteración de los gestos corporales del mono Casma en las vasijas tricolor o con huellas de

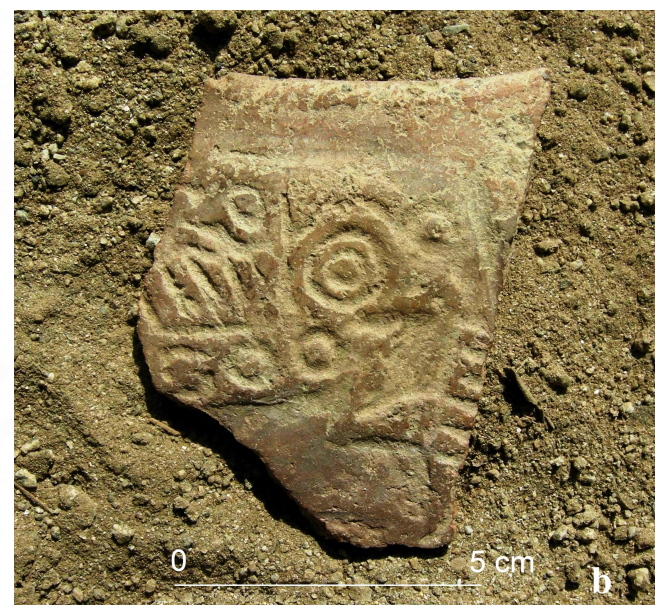

Figura 12. (a) Vasija de Pativilca con relieve de "diosa lunar" y animales (Carrión Cachot 1955:fig. 6). (b) Fragmento de cerámica moldeada con ave mítica, Proyecto Pallka UNASAM (foto J. Gamboa).

Pativilca vessel with "lunar goddess" and animal relief(Carrion Cachot 1955:fig. 6). (b) Ceramic fragment molded with mythical bird (photograph by J. Gamboa) 
uso doméstico puede ser objeto de una primera, y simple, interpretación de "clases populares copiando modelos de élite". Una alternativa distinta es considerar la existencia de conceptos sobre el cuerpo y agencia (de los monos y más allá de ellos) comunes a distintos niveles socioeconómicos. Un caso de mímesis corporal Casma es aquí identificado en los recipientes cerámicos con motivos incisos (Figura 11). Estas piezas carecen de rasgos antropomorfos, pero muestran morfologías sugerentes de que las corporalidades humanas y de los cántaros eran percibidas como intercambiables. La parte superior de las vasijas -pero también de aquellas más pequeñas y finas- solían mostrar, al igual que el cuerpo humano vestido, mayor decoración. Como espacios de ingreso y salida de substancias, el cuello y la boca del cántaro representaban, si seguimos este argumento, la cabeza de un individuo'. En el pensamiento Casma algunos cántaros pudieron ser asumidos como seres sociales reconocibles y activos. Parafraseando a Swenson (2015:698), esas vasijas no habrían sido experimentadas y percibidas como contenedores inertes sino como elementos provistos de fuerza y capacidades propias, mutables y aun animadoras. Esta posibilidad permite entender la (tenaz) presencia de los monos junto a los golletes, aún en aquellos sin rostros "visibles".

Existe un tema adicional. ¿Era el mono para los Casma y otras sociedades prehispánicas un sujeto o un "subjected companion", en el sentido de Swenson (2015:683)? En diferentes periodos y sociedades prehispánicas los primates traídos desde los bosques lluviosos fueron objetos de crianza, sacrificio y ofrenda (como en Ventarrón o Pachacamac), mostrando en cada instancia una agencia dependiente o mediada por otros. Sin embargo, la diferencia entre los estados arriba señalados no siempre es reconocible en el registro iconográfico o contextual.

\section{Seres de entendimiento}

Los primates eran animales estimados (tanto como sometidos) por las poblaciones prehispánicas de los Andes Centrales, quienes los asociaron a figuras humanas y divinas. Recurriendo a un concepto presentado por Thérèse Bouysse-Cassagne, podemos considerar que para los Casma y sus vecinos los monos eran "animales de entendimiento", una categoría que implica el reconocimiento de "relaciones de parentesco, capacidades de comunicación, subjetividad y formas de intercambio mediante el lenguaje, lo que tiende a hacernos pensar en formas de interioridades muy parecidas" entre los humanos y otras especies (Bouysse-Cassagne 2018:699). Ver a los monos de la sociedad Casma como seres agentivos, un aspecto considerado por la antropología multiespecies, permitiría avanzar en la comprensión de los vínculos interespecies aquí identificados. Pero, ¿en qué sentido debemos concebir esa capacidad de entendimiento? En este punto debemos reconocer que esa atribución recae sobre una base aún frágil. La creencia en relaciones ancestrales de parentesco, uno de los puntos señalados por Bouysse-Cassagne, puede ser considerada en este y otros casos de estudio, pero, frente a la falta de fuentes documentales o iconográficas explicitas, resulta difícil de probar. A diferencia de lo que sucede para Moche, la transmutación animal/humano y humano/animal no se manifiesta claramente en el corpus visual Casma. Nuestra comprensión de la capacidad de comunicación en el pasado entre humanos y primates recae, con el riesgo implícito del anacronismo, en la apreciación de patrones conductuales visibles en la actualidad.

Bouysse-Cassagne (2018:699) indica que las "normas culturales" no son exclusivas del hombre, apareciendo en animales valorados precisamente por contar con capacidades organizativas y agentivas. A partir de ese punto, la autora señala el uso en los Andes de metáforas descriptivas y rasgos ontológicos humanos para categorizar a ciertos animales como individuos con propiedades antrópicas, entre ellas el habla. En el pensamiento indígena prehispánico tardío y colonial esa última capacidad llegaba a ser "evidente" cuando el animal era interrogado o solicitado correctamente. El mono y otras especies animales de la iconografía prehispánica tardía de la costa norcentral eran seres próximos a personajes que materializaban diversas formas de autoridad y capacidad animadora. Los monos incluso podían entrar en contacto directo (mediante su cercanía física y el gesto explícito del contacto corporal) con esos individuos, algo negado o considerado no necesario para otras especies. Esa relación habría resaltado la capacidad especial, propia o adquirida, de algunos individuos -líderes, curanderos, sacerdotes o músicos- de entrar en contacto y comunicarse con el mundo silvestre. Por otra parte, la cercanía entre el mono y los cántaros, un vínculo explícito en las escenas Moche en que un primate vestido de sacerdote sujetaba "a cuatro patas" uno de esos recipientes (Figura 13a), pudo ser interpretada como una alegoría tanto del animal sediento como del consumo de líquidos y chicha.

\section{Rutas de Intercambio}

La ausencia de mercados basados en el capital monetario no fue impedimento para el desarrollo de formas complejas de intercambio económico en los Andes Centrales. El tráfico a través de la costa norcentral pudo tener una posición importante en las interacciones regionales que vinculaban los territorios Lambayeque y 

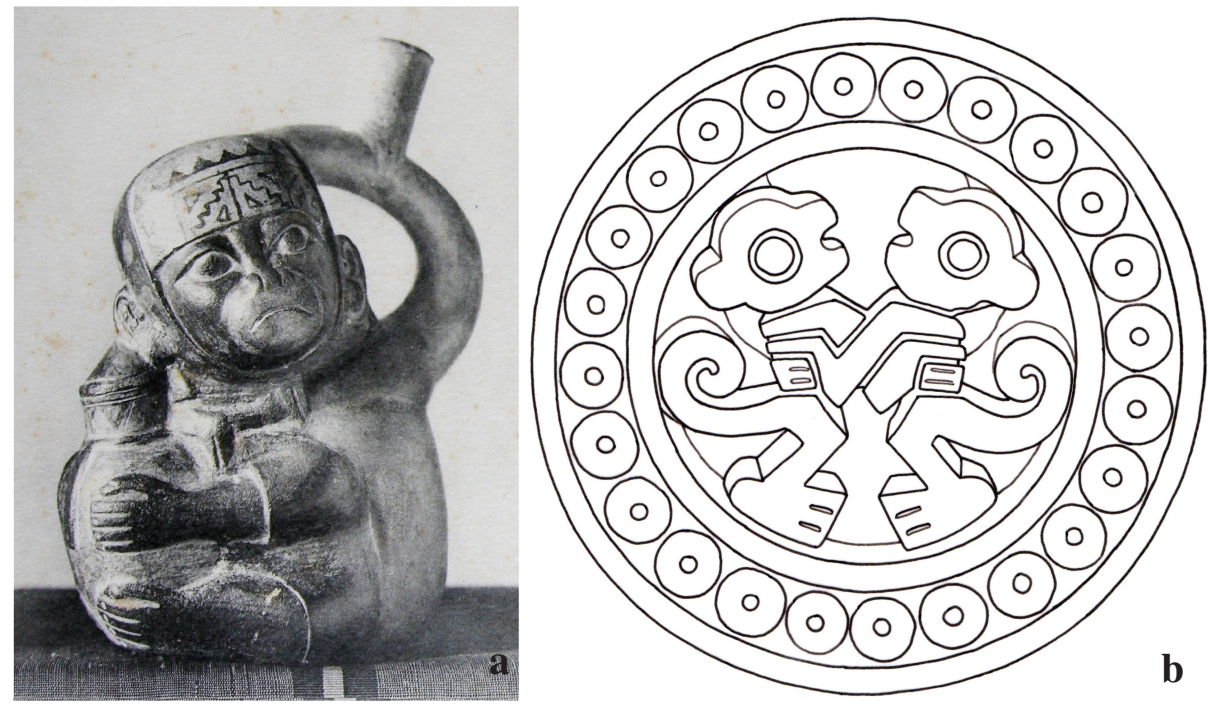

Figura 13. (a) Vasija Moche con mono antropomorfo sosteniendo un cántaro (d'Harcourt y d'Harcourt 1924fig:lám. 53a). (b) Orejeras de madera de Castillo de Huarmey (adaptado de Giersz 2016:fig. 25).

Moche vessel with anthropomorphic monkey holding a pitcher (d'Harcourt 1924fig:plate. 53 ${ }^{a}$ ). (b)Wooden ear muffs from Castillo de Huarmey (adapted from Giersz 2016:fig.25).

Chimú con la costa central. Batán Grande y Chan Chan, entre otros centros regionales, contaban con el espacio Casma para alcanzar las zonas Chancay e Ichma. La articulación con la costa y la chaupiyunga (500-2.300 msm) era asimismo vital para la obtención de recursos marinos, sal y ciertos alimentos por las sociedades altoandinas de Ancash. El bajo número de trabajos enfocados en la interacción regional prehispánica tardía complica la caracterización de tales contactos, pero el panorama de ese tipo de aproximación territorial a las sociedades regionales es promisorio.

¿Qué rutas pudieron ser empleadas para la introducción de los primates en la costa norcentral? La travesía marítima es una opción poco explorada. Caracterizada por una línea de playa accidentada, el litoral de Ancash presenta fuertes corrientes marinas de sur a norte. Algunos puertos coloniales continúan siendo empleados, pero se carece de datos etnohistóricos o etnográficos sobre la navegación indígena regional (compárese con Prieto 2016). Las rutas terrestres son mejor conocidas. Los caminos que cruzaban el paisaje Casma fueron empleados (y remodelados) en los periodos Chimú e Inca para el tráfico de personas, animales de carga y bienes (Chávez 2017; Pimentel y Paredes 2003; Wilson 1988:292). Durante la colonia, parte de esas mismas vías sirvieron para el movimiento de autoridades europeas e indígenas y el traslado de poblaciones y productos. Un ejemplo de 1582 para Nepeña señala el uso y administración del tambo de Guambacho por don Juan CuyCuy, cacique principal local y alguazil, Gonzalo Enepena, segunda persona y quipucamayo, y el tavernero Alonso Pingo (Moore 1995:171, 173).

El intercambio económico precolonial iba igualmente dirigido hacia la sierra; para ello se empleaban los caminos que ascendían los valles, como los de Huambacho-Moro, Casma-Cayanpunta, y Fortaleza-Conococha-Pampa de Lampas (Barr 2013; Bernabé 2017). El empleo de esos caminos debe ser entendido como parte del uso de los corredores naturales que llevan de la costa a la sierra norcentral y de allí al Alto Marañón y los valles cálidos, ricos en recursos, pero distantes de la selva alta. Un primer corredor es el de Santa-Tablachaca-Pataz-Abiseo; otro articulaba Casma con Huaraz, partiendo luego a Huántar, Huacaybamba y Llata en Huánuco. La vía que se iniciaba en el Valle de Fortaleza conducía a Chavín de Huántar, Chiquián y las nacientes del Río Marañón.

Las poblaciones Casma pudieron contar con diferentes medios para acceder a los recursos de la cuenca amazónica. Los monos machines, araña y aulladores o coto (Alouatta sp.) habitan los bosques lluviosos de San Martín y Huánuco, dos probables fuentes de los primates empleados por las sociedades de la costa y sierra de Ancash. La subespecie Cebus albifrons aequatorialis está presente en Tumbes; esa lejana localidad septentrional era otra opción para obtener los monos machines. Una tercera ruta estaba formada por las cuencas nororientales del Utcubamba y Chiriaco, en Chachapoyas y Bagua, dos regiones productoras de semillas de ishpingo (Nectandra 
sp.) que pudieron ofrecer sus productos tanto a las poblaciones de Cajamarca como a las del área Chimú.

\section{Identidades y Jerarquías Humanas y Animales}

Las ontologías creadas en torno al mono Casma parecen haber dado poca atención a su conversión hacia lo humano o sobrenatural. A diferencia de lo mostrado en la iconografía Chimú y Lambayeque, los monos Casma tampoco fueron figurados con correas atadas a la cintura, aun en aquellos casos de cercanía al cuerpo del gobernante. Consideremos la posibilidad de establecer algunas analogías. ¿Qué personajes humanos se encontraban en proximidad física y simbólica a los jefes? En un primer lugar hallaríamos a individuos con roles en el gobierno y el ceremonial político y religioso. Esos personajes -un grupo amplio que pudo incluir varones y mujeres, consejeros, sacerdotes, artistas, guerreros y especialistas en el tráfico regional- habrían adquirido un papel político complementario, a la vez que codependiente, frente a los jefes de turno. La naturaleza relacional de esos individuos provistos de autoridad a la vez que subordinados resulta evidente. Las orejeras con figuras de mono de Castillo de Huarmey (Figura 13b) y los monos que rodeaban la cabeza de los cántaros pintados deben ser entendidas como parte de un conjunto de metáforas visuales y narrativas originalmente dirigidas a resaltar la capacidad de oír (y ser escuchado) del gobernante "Casma".

Esa asociación entre seres del bosque y autoridad distaba de ser nueva. Algunos individuos Moche de alto rango usaban tocados con la cabeza escultórica de un mono, a veces feroz, identificable como Cebus, Sapajus o Saimiri (compárese con Alaica 2018:869870); en otras ocasiones, un varón adulto bien vestido y sentado sostenía un mono (Donnan 2004:17, 61, 118). La centralidad visible en los grupos animal-humanoanimal Casma es comparable a la organización icónica de algunas escenas Moche, Recuay o, para las tradiciones sureñas, Pucara, Tiwanaku y Wari. Lejos de ser "secundario", el significado de los seres zoomorfos laterales presentes en esos registros pudo estar sujeto a relaciones cambiantes de complementariedad y subordinación. La centralidad y marginalidad figurativa Casma alude, a todas luces, a conceptos de localidad, foraneidad y otredad, pero ese modelo explicativo aclara solo en términos generales el significado de las imágenes. Otros aspectos de la identidad del mono para los Casma y sus vecinos -como su valor como objeto transcultural- deberán ser comprobados por la arqueología y los estudios zooarqueológicos.

La relación frecuente en Chimú y Lambayeque entre monos y alimentos vegetales como el maíz y el pacae (Inga feuillei) no es explicita en la cultura visual Casma. No obstante, un vínculo comparable emerge cuando observamos la aparición de los monos de la costa norcentral en vasijas usadas para contener líquidos o que representaban a seres humanos y sobrenaturales potencialmente asociados -como las serpientes bicéfalas, los felinos y los personajes con tocados y cetros- a la procuración y entrega de sustento. Sin ser uniformes, las ideologías andinas precoloniales tendían a presentar a los primates como símbolos de autoridad, fertilidad y otredad, convirtiéndolos, al mismo tiempo, en soportes animados de la memoria social y referentes de espacios (o tiempos) de origen. Probar la existencia o manifestaciones particulares de esos conceptos entre los Casma es tanto un reto como una invitación a abrir nuevas líneas de investigación sobre los sistemas iconográficos andinos y la complejidad social del pasado.

\section{Comentarios Finales}

La coexistencia entre comunidades humanas y animales incorpora una vasta serie de alteridades, idealizaciones y formas de subordinación con consecuencias culturales y éticas que encuentran sentido en la permanente (re)construcción de fronteras conceptuales, categorías y dependencias (Rose et al. 2012). La identificación del mono en la tradición Casma ofrece la oportunidad para cubrir un vacío en la comprensión de la presencia y significado de los primates del Neotrópico entre las sociedades prehispánicas tardías de los Andes Centrales. Los antecedentes regionales de esas imágenes parecen encontrarse mayormente en el periodo Moche (100-800 DC), durante el cual los monos fueron relacionados a rituales de mascado de coca y presentación de ofrendas. Las figuras de un primate con frutos, cargando literas, o siendo conducido por un ser humano serían frecuentes en las regiones Chimú y Lambayeque (900-1450 DC), perdurando en ellas hasta el dominio Inca de la costa norte y norcentral (1450-1532). El rol del mono en la ideología regional no desaparecería con la conquista hispana. En el presente, los monos continúan siendo personajes de la literatura oral y las memorias de las poblaciones campesinas y urbanas del área, especialmente en Lambayeque, donde son evocados como seres del monte y signos del desenfreno (Narváez 2014:289-290).

Cabe indicar que el género de los monos representados en la cerámica Casma no es evidente. El dimorfismo sexual de los machines, monos araña y monos choro Lagothrix flavicauda -criados por las poblaciones indígenas y mestizas modernas de la Amazonia y los Andes- es poco marcado. El mono aullador, el primate más grande de los bosques sudamericanos, exhibe dimorfismo, pero es poco proclive a vivir fuera de su hábitat natural. El enfasis en la sexualidad masculina identificado por Scher (2012) para la iconografía 
cerámica Moche no parece haber sido enfatizado en la costa norcentral. Un aspecto adicional a comprender es el valor o sentido de las cabezas con doble rostro ocasionalmente asociadas a las figuras de primates. La cerámica prehispánica tardía de la costa de Ancash incluía con cierta frecuencia personajes con dos rostros. Los antecedentes de la faz múltiple, humana o animal, corresponderían más al estilo Moche -donde algunas cabezas presentan hasta cuatro caras confluyentesque a Wari (Giersz et al. 2005:220-222).

La identificación de vínculos entre los cántaros Casma con la representación de un individuo, a veces bebiendo, flanqueado por monos y las vasijas con cuello no figurativo rodeado por dos monos demuestra, como viéramos antes, la relación entre primates, recipientes con (de manera real o metafórica) líquidos, y prácticas sociales de comensalismo y reciprocidad que podían incluir el consumo de chicha. La producción preChimú de chicha en el valle de Casma (Pozorski y Pozorski 2012:226-227; Vogel 2016:171-172) era un proceso de socialización que permitía la transformación (mediante molienda, hervido y fermentación) del maíz en una bebida alcohólica dulce y rica en nutrientes. Las ollas y cántaros más amplios servían para la cocción y fermentado, pero la distribución y servido de la chicha implicaba el uso de cántaros y cuencos de pastas finas con frecuencia decorados. El periodo de influencia Chimú en la costa norcentral continuó siendo de elaboración intensiva de chicha. En Manchán esa actividad se concentró en un sector popular ocupado por varones y mujeres a cargo de suministrar la bebida consumida en festividades y eventos públicos (Moore 1989:692).

Aunque basada en el aprovechamiento de los recursos locales, la administración Chimú de Manchán no trasformó radicalmente la política y economía comunitarias de la costa norcentral (Moore 1989; Prządka 2012:331). Durante ese mismo tiempo y hasta el siglo XVII, la Cordillera Negra, el espacio geográfico y cultural inmediatamente al este del territorio Casma, fue otra zona de producción de chicha. La información colonial temprana para esa área, producida en un escenario de represión de las religiones nativas, ayuda a observar el carácter humano de esa actividad y su frecuente superposición a cuestiones de género y especialización socioeconómica (Arana 2017:131-133; Hernández Príncipe 1923 [1622]). Ninguno de esos documentos hace mención a los monos y otros seres de la selva. Avanzado el periodo Colonial, los sistemas regionales de intercambio que conectaban la costa de Ancash con las tierras cálidas del Marañón y los bosques amazónicos fueron alterados y reorientados. Dos puntos cruciales en esa disrupción fueron la prohibición, impuesta o cooptada, de los patrones culturales indígenas y la debacle demográfica nativa costeña.

La materialidad y las construcciones ontológicas (variables incluso en una región y tiempo) no deben ser tratadas como uniformes o parte de un mismo fenómeno (Swenson 2015:679-680). Ese último punto ha sido de interés a nuestro trabajo. Las sociedades Casma, Chimú y Lambayeque (o las poblaciones más tempranas Moche), siendo contemporáneas, no necesariamente compartieron concepciones análogas sobre los primates y su(s) significado(s). La relación de determinados animales a las jerarquías sociales o al consumo de bebidas mostraba rasgos comparables, pero no idénticos, entre las sociedades prehispánicas costeñas del norte y centro de Perú. La naturaleza cautiva o libre del mono y su proximidad al cuerpo del gobernante son aspectos igualmente diferenciables.

Antes de concluir este artículo debemos regresar a las categorías oponibles de silvestre y doméstico señaladas por Alaica (2018:864). El mono de la costa norcentral era un ser en posición liminal, originario de los bosques tropicales pero adaptado, de manera forzada, a los asentamientos humanos. Esa forma de existencia en un medio normativo antrópico a la vez que natural convertía al mono en una entidad disruptiva de la distinción entre lo salvaje y lo disciplinado. Sin duda, se requiere de mayor información contextualizada y zooarqueológica sobre las relaciones entre los pueblos de la costa norcentral y los primates que criaban o representaban. No obstante, es evidente que el simbolismo de los primates en el área cultural Casma dependía de los vínculos ideados entre ese animal y las jerarquías humanas. No solo ello. La interacción entre la costa norcentral y las regiones tropicales norteñas y orientales -probada por la presencia y agencia del mono en el territorio Casma-, demuestra, una vez más, que las sociedades andinas precoloniales nunca se desarrollaron en aislamiento, sino en un escenario dinámico y cambiante de interacción y contactos.

Agradecimientos: El autor desea expresar su reconocimiento a Alfredo Bar, Joseph Bernabé, Antonio Jaramillo, Robert Markens, Kerstin Nowack, Verónica Ortega, Juan Paredes, Hoover Rojas, Eladio Terreros y Aldo Watanave por sus comentarios y continua colaboración. Manuel Escobar, Adrián Villón y Carlos Broncano brindaron una cálida bienvenida en Nepeña. La redacción final del manuscrito se realizó en la Facultad de Ciencias Sociales, Educación y Comunicación de la UNASAM, contándose allí con el cordial apoyo de sus autoridades y docentes. El manuscrito se benefició de la contribución de varios evaluadores anónimos, quienes aportaron una valiosa mirada crítica a la investigación. 


\section{Referencias Citadas}

Alaica, A. 2018. Partial and complete deposits and depictions: Social zooarchaeology iconography and the role of animals in Late Moche Peru. Journal of Archaeological Science: Reports 20:864-872.

Alva, I. 2013. Ventarrón y Collud. Origen y Auge de la Civilización en la Costa Norte del Perú. Ministerio de Cultura del Perú y Proyecto Especial Naylamp, Lima.

Arana, L. 2017. '... siendo tan biejos siegas tullidas mal de coraçon...' ': Un proceso a ancianos 'hechiceros' en San Jerónimo de Pampas (Huaylas, 1647). Revista del Instituto Seminario de Historia Rural Andina 2 (3):127-142.

Baker, M. 1992. Capuchin monkeys (Cebus capucinus) and the Ancient Maya. Ancient Mesoamerica 3:219-228.

Barr, A. 2013. El Proyecto Qhapaq Ñan y el registro del Sistema Vial Inca. El camino Inca Huaraz-Casma. http://repositorio. cultura.gob.pe/handle/CULTURA/176 (14 septiembre 2019).

Bastiand, M. 2006. El estilo de la cerámica Casma del Intermedio Tardío. Investigaciones Sociales UNMSM 10 (17):91-119.

Bélisle, V. 2008. El Horizonte Medio en el valle de Santa: Continuidad y discontinuidad con los mochicas del Intermedio Temprano. En Arqueología Mochica. Nuevos Enfoques, editado por L.J. Castillo, H. Bernier, G. Lockard y J. Rucabado, pp. 17-31. PUCP e IFEA, Lima.

Benson, E.1997. Birds and Beasts of Ancient Latin America. University Press of Florida, Gainesville.

Bernabé, J. 2017. La ruta Inca a los Huaylas. Vialidad inca en la Pampa de Lampas-Choquerecuay, Ancash. Boletín del Museo Chileno de Arte Precolombino 22 (2):47-63.

Bertonio, L. 1612. Segunda Parte del Vocabulario en la qval por orden del A B C se ponen en primer lugar los vocablos de la Lengua Aymara para hallar los que le corresponden en la Española. Juli, Provincia de Chucuito.

Bourget, S. 2006. Sex, Death, and Sacrifice in Moche Religion and Visual Culture. University of Texas Press, Austin.

Bouysse-Cassagne, T. 2018. "La piel que habito". De algunos mecanismos de aparejamientos ontológicos entre humanos y animales en los Andes del Sur. En Interpretando Huellas: Arqueología, Etnohistoria y Etnografía de los Andes y sus Tierras Bajas, editado por M. Muñoz, pp. 697-719. Editorial Kipus, Cochabamba.

Burger, R. y L. Salazar 2015. La cerámica de Coscopunta, un sitio del Periodo Intermedio Tardío en Carhuaz, Callejón de Huaylas, Perú. Boletín IFEA 44 (1):23-52.

Carrión Cachot, R. 2005 [1955]. El culto al Agua en el Antiguo Perú. Museo Nacional de Antropología y Arqueología. Reedición del Instituto Nacional de Cultura, Lima.

Castillo, F. 2018. Tipología y seriación de la cerámica proveniente del cementerio Chimú de Huaca de la Luna, Perú. Boletín del Museo Chileno de Arte Precolombino 23 (2):27-58.

Chapdelaine, C., V. Pimentel G. Gagné, J. Gamboa, D. Regalado y D. Chicoine 2004. Nuevos datos sobre Huaca China, valle del Santa, Perú. Boletín IFEA 33 (1):55-80.

Chapdelaine, C., V. Pimentel y J. Gamboa 2009. Rol de la cerámica en la afirmación social de los Moches del valle de Santa. Revista Chilena de Antropología 20:37-76.
Chávez, J. 2017. El camino de los llanos entre Paramonga y Santa: Revisión de los caminos incas de la costa norcentral del Perú. Haucaypata 12:23-38.

Chinchilla, O. 2010. Of birds and insects: The hummingbird myth in Ancient Mesoamerica. Ancient Mesoamerica 21:45-61.

Collier, D. 1955. Cultural Chronology and Change as Reflected in the Ceramics of the Virú Valley, Perú. Chicago Natural History Museum, Chicago.

Daggett, C. 1983. Casma Incised pottery: Analysis of collections from the Nepeña Valley. En Investigations of the Andean Past, editado por D. Sandweiss, pp. 209-225. Cornell University Press, Ithaca.

Descola, P. 2005. Beyond Nature and Culture. University of Chicago Press, Chicago.

d'Harcourt, R. y M. d'Harcourt 1924. La Ceramique Ancienne du Perou Albert Morance, Paris.

Donnan, C. 2004. Moche Portraits from Ancient Peru. University of Texas Press, Austin.

Donnan, C. y C. Mackey 1978. Ancient Burial Patterns of the Moche Valley, Peru. University of Texas Press, Austin.

Donnan, C. y D. McClelland 1999. Moche Fineline Paintings. Its Evolution and Its Artists. UCLA Fowler Museum of Cultural History, Los Angeles.

Echevarría, J. 2015. Los excesos del mono: Salvajismo, transgresión y deshumanización en el pensamiento nahua del siglo XVI. Journal de la Société des Américanistes 101 (1):137-172.

Eeckhout, P. 2004. Relatos míticos y prácticas rituales en Pachacamac. Boletín del Instituto Francés de Estudios Andinos 33 (1):1-54.

García, M., F. Gili, J. Echeverría, E. Belmonte y V. Figueroa 2018. $\mathrm{K}$ 'oa, entidad andina de una planta y otros cuerpos. Una posibilidad interpretativa para ofrendas funerarias en la arqueología de Arica. Chungara Revista de Antropología Chilena 50 (4):537-556.

Giersz, M. 2016. Castillo de Huarmey: Centro político Wari en la costa norte del Perú. En Andes 9. Nuevas Perspectivas en la Organización Política Wari, editado por M. Giersz y K. Makowski, pp. 217-262. Warsaw University e IFEA, Lima.

Giersz, M., K. Makowski y P. Prządka 2005. El Mundo Sobrenatural Mochica. Imágenes Escultóricas de las Deidades Antropomorfas en el Museo Arqueológico Rafael Larco Herrera. PUCP, Lima.

Giersz, M. y P. Prządka 2009. Cronología cultural y patrones de asentamiento en el valle de Culebras, Costa Norcentral de Perú. Arkeos 4 (11):1-40.

Götz, C. y K. Emery (eds.) 2013. The Archaeology of Mesoamerican Animals. Lockwood Press, Atlanta.

Haraway, D. 2008. When Species Meet. University of Minnesota Press, Minneapolis.

Hernández Príncipe, R. 1923 [1622]. Idolatrías en Recuay. Idolatría del pueblo de Ocros cabeza desta comunidad. Año de 1621. Relación de la visita del pueblo de Santa María Magdalena doctrina de Marca, provincia de Huailas. Anno de 1621. Revista Inca 1:25-78.

Kirksey, S.E. y S. Helmreich 2010. The emergence of multispecies ethnography. Cultural Anthropology 25 (4):545-576.

Knobloch, P. 2005. Monkey saw, monkey did: A stylization model for correlating Nasca and Wari chronology. Andean Past 7:111-134. 
Koschmieder, K. 2012. Estrategias de subsistencia en la periferia sur del imperio Chimú: El caso de Puerto Pobre, Casma. En Andes 8. Arqueología de la Costa de Ancash, editado por M. Giersz e I. Ghezzi, pp. 399-448. Warsaw University e IFEA, Lima.

Kroeber, A. 1925. The Uhle Pottery Collections from Supe. University of California Publications in American Archaeology and Ethnology 21(6), Berkeley.

Mackey, C. y U. Klymyshyn 1990. The southern frontier of the Chimú empire. En The Northern Dynasties: Kingship and Statecraft in Chimor, editado por M. Moseley y A. CordyCollins, pp. 195-226. Dumbarton Oaks, Washington DC.

McClelland, D., D. McClelland y C. Donnan 2007. Moche Fineline Painting from San José de Moro. Cotsen Institute of Archaeology, Los Angeles.

Moore, J. 1989. Pre-Hispanic beer in Coastal Peru: Technology and social context of prehistoric production. American Anthropologist 91 (3):682-695.

Moore, J. 1995. The archaeology of dual organization in Andean South America: A theoretical review and case study. Latin American Antiquity 6 (2):165-181.

Morgan, A. 1996. The Pre-Columbian Pottery Figurines of the Central Coast of Peru. Institute of Archaeology, University College London, London.

Moseley, M. 1992. The Incas and Their Ancestors. Thames and Hudson, Londres.

Narváez, A. 2014. Dioses, Encantos, y Gentiles. Introducción al Estudio de la Tradición Oral Lambayecana. Ministerio de Cultura y Museo Túcume, Chiclayo.

Paul, A. 1991. Paracas Art and Architecture. University of Iowa Press, Iowa City.

Pimentel, V. y M. Paredes 2003. Evidencias Moche V en tambos y caminos entre los valles de Santa y Chao. En Moche: Hacia el Final del Milenio, editado por S. Uceda y E. Mujica, pp. 269-304. Fondo Editorial PUCP y Universidad Nacional de Trujillo, Lima.

Pozorski, S. y T. Pozorski 2012. Exploring access control at Taukachi Tardío. Ñawpa Pacha 32 (2):207-230.

Prieto, G. 2016. Balsas de totora en la costa norte del Perú: Una aproximación etnográfica y arqueológica. Quingnam 2:141-188.

Proulx, D. 1968. An Archaeological Survey of the Nepeña Valley, Peru, Research Report 2. Department of Anthropology, University of Massachusetts, Amherst.

Prümers, H. 2000. El Castillo de Huarmey: Una plataforma funeraria del Horizonte Medio. Boletín de Arqueología PUCP 4:289-312.

Prządka, P. 2012. La presencia Casma, Chimú e Inca en el valle de Culebras. En Andes 8. Arqueología de la Costa de Ancash, editado por M. Giersz e I. Ghezzi, pp. 327-255. Warsaw University e IFEA, Lima.

Reitz, E. 2003. Resource use through time at Paloma, Peru. Bulletin of Florida Museum of Natural History 440:65-80.

Rice, P. y K. South 2015. Revisiting monkeys on pots: A contextual consideration of primate imagery on Classic Lowland Maya pottery. Ancient Mesoamerica 26:275-294.
Rose, D.B., T. Van Dooren, M. Chrulew, S. Cooke, M. Kearnes y E. O'Gorman 2012. Thinking through the environment, unsettling the humanities. Environmental Humanities 1:1-5.

Samaniego, L. 1974. Informe general sobre las excavaciones y restauraciones en Sechín, 1971-1974. Archivos del Museo de sitio de Cerro Sechín, Casma.

Samaniego, L. 1982. Sechín. Monumento Arqueológico en la Costa Norte. Instituto Nacional de Cultura, Casma.

Scher, S. 2012. Markers of masculinity: Phallic representation in Moche art. Boletín IFEA 41 (2):169-196.

Shady, R. y C. Leyva (eds.) 2003. La Ciudad Sagrada de Caral-Supe. Instituto Nacional de Cultura, Lima.

Strong, D. y C. Evans 1952. Cultural Stratigraphy in the Viru Valley, Northern Peru. Columbia University Press, New York.

Swenson, E. 2015. The materialities of place making in the ancient Andes: A critical appraisal of the ontological turn in archaeological interpretation. Journal of Archaeological Method and Theory 22:677-712

Tello, J.C. 1956. Arqueología del valle de Casma. Culturas Chavín, Santa o Huaylas Yunga y Sub-Chimú. Editorial San Marcos, Lima.

Thompson, D. 1964. Archaeological investigations in the Huarmey Valley, Peru. Proceedings of the 36th International Congress of Americanists 1:541-548, Madrid.

Trever, L., J. Gamboa, R. Toribio y R. Morales 2017. The Archaeology of Mural Painting at Pañamarca, Peru. Dumbarton Oaks, Washington DC

Van Dooren, T., S.E. Kirksey y U. Münster 2016. Multispecies studies. Cultivating arts of attentiveness. Environmental Humanities 8 (1):1-23.

Viveiros de Castro, E. 1992. From the Enemy's Point of View: Humanity and Divinity in an Amazonian Society. University of Chicago Press, Chicago.

Viveiros de Castro, E. 1998 Cosmological deixis and Amerindian perspectivism. Journal of the Royal Anthropological Institute 4 (3):469-488.

Vogel, M. 2011. Style and interregional interaction: Ceramics from the Casma capital of El Purgatorio. Ñawpa Pacha 31:201-224.

Vogel, M. 2012. Frontier Life in Ancient Peru: The Archaeology of Cerro la Cruz. University Press of Florida, Gainesville.

Vogel, M. 2016. The Casma Capital City of El Purgatorio: Ancient Urbanism in the Andes. University Press of Florida, Gainesville.

Vogel, M. 2018. New research on the late prehistoric coastal polities of northern Peru. Journal of Archaeological Research 21 (3):165-195.

Weismantel, M. 2015. Many heads are better than one: Mortuary practices and ceramic art in Moche society. En Living with the Dead in the Andes, editado por I. Shimada y J. Fitzsimmons, pp. 76-100. University of Arizona Press, Tucson.

Wilson, D. 1988. Prehispanic Settlement Patterns in the Lower Santa Valley, Peru: A Regional Perspective on the Origins and Development of Complex North Coast society. Smithsonian Institution Press, Washington DC.

Zavaleta, E. y R. Sánchez 2013. El complejo arqueológico Campanario y la presencia de cerámica Casma en el valle de Huarmey. Arqueología y Sociedad 26:131-164. 


\section{Notas}

${ }^{1}$ Los contactos entre el área Casma y la sierra de Ancash son visibles en la presencia de tipos cerámicos comparables en esa última región (Burger y Salazar 2015).

${ }^{2}$ La reproducción en cautiverio de primates en los Andes precoloniales no ha sido probada.

3 El Vocabulario Aymara de Ludovico Bertonio (1612:255) definía el vocablo "Phaxcha" como: “....instrumento de madera con que beben chicha por pasatiempo corriendo encañada. Y cualquiera cosa que corra, o salga por caño se llama Phakhcha”. En las vasijas de la costa norcentral los monos podían rodear a una pareja en acto sexual, una escena originada en el estilo Moche (Donnan y McClelland 1999:fig. 4.95; Kroeber 1925:lám. 78o para un ejemplo moldeado de Supe) en la que una planta podía nacer del cuerpo del personaje masculino.

${ }^{4}$ Swenson (2015:683) observó una posible situación en la que "declaring Andean “(meta)physics of being” as relational as opposed to substantivist or representational (Cartesian) leaves many questions unanswered and poses the threat of reductively obscuring considerable diversity", un punto a ser considerado al tratar sobre el significado de los personajes iconográficos y sus roles sociales.
5 Cuando nos referimos a "alfareros" no se pretende asumir que el manejo de los espacios de producción cerámica fuera exclusivamente masculino. La utilización de moldes por los Casma, como entre los Moche, permitía reproducir imágenes y tendencias estilistas populares, pero también significaba el desarrollo de conocimientos y formas de manipulación del simbolismo de las imágenes (Chapdelaine et al. 2009:55).

6 Aunque proceden de excavaciones no documentadas, esos materiales merecen ser descritos, y preservados por su significado arqueológico y patrimonial.

7 Daggett (1983:289) señaló la presencia de cerámica con círculos y puntos impresos en el valle de Fortaleza, al sur de Huarmey; la existencia de materiales con decoración incisa en esa área fue también mencionada por Thompson (1964:545).

${ }^{8}$ El fragmento cerámico en la Figura 12 b fue registrado por el Proyecto Arqueológico Pallka de la Universidad Nacional Santiago Antúnez de Mayolo (2012-2015) dirigido por Cesar Serna.

9 Ver Scher (2012) y Weismantel (2015) para la discusión del significado de la cabeza en el periodo Moche. 
